\title{
Characterising socio-economic inequalities in exposure to air pollution: a comparison of socio-economic markers and scales of measurement
}

\author{
Anna Goodman ${ }^{1}$, Paul Wilkinson ${ }^{2}$, Mai Stafford ${ }^{3}$, Cathryn Tonne $e^{4,5}$
}

1 Faculty of Epidemiology and Population Health, London School of Hygiene and Tropical Medicine, London, UK

2 Faculty of Social and Environmental Health Research, London School of Hygiene and Tropical Medicine, London, UK

3 Epidemiology \& Public Health, UCL Division of Population Health, London, UK

4 Faculty of Social and Environmental Health Research, London School of Hygiene and Tropical Medicine, London, UK

5 MRC-HPA Centre for Environment and Health, Faculty of Medicine, Imperial College London, London, UK

Corresponding author: Cathryn Tonne, Department of Social and Environmental Health Research , London School of Hygiene and Tropical Medicine, 15-17 Tavistock Place, London, WC1H 9SH, UK. Email: cathryn.tonne@1shtm.ac.uk

Note: this is a personal version, created by Anna Goodman, of the text of the accepted journal article. It reflects all changes made in the peer review process, but does not incorporate any minor modifications made at the proof stage. The complete citation for the final journal article is:

- Goodman, A; Wilkinson, P; Stafford, M; Tonne, C; (2011) Characterising socioeconomic inequalities in exposure to air pollution: A comparison of socioeconomic markers and scales of measurement. Health Place, 17 (3). pp. 767-74

- DOI: 10.1016/j.healthplace.2011.02.002

Copyright (C) and Moral Rights for this paper are retained by the individual authors and/or other copyright owners 


\begin{abstract}
$\underline{\text { Abstract }}$
This study examines traffic-related air pollution in London in relation to area- and individual-level socio-economic position (SEP). Mean air pollution concentrations were generally higher in postcodes of low SEP as classified by small-area markers of deprivation (Index of Multiple Deprivation (IMD) domains) and by the postcode-level ACORN geodemographic marker. There were exceptions, however, including reversed directions of associations in central London and for SEP markers relating to education. ACORN predicted air pollution independently of IMD and explained additional variation at the postcode level, indicating the potential value of using both markers in air pollution epidemiology studies. By contrast, after including IMD and ACORN there remained little relationship between air pollution and individual-level SEP or smoking, suggesting limited residual socio-economic confounding in epidemiological studies with comprehensive area-level adjustment.
\end{abstract}

Keywords: Air pollution, socioeconomic factors, area deprivation, methods, confounding factors

\title{
$\underline{\text { Introduction }}$
}

Exposure to traffic-related air pollution is associated with numerous adverse health effects, including all-cause mortality ${ }^{1-5}$, cardiovascular events ${ }^{2,6-8}$, lung cancer ${ }^{2,9}$, and respiratory outcomes in children ${ }^{10,11}$. Individuals of low socio-economic position (SEP) may be more exposed to air pollution and also more susceptible to these adverse health effects ${ }^{12-16}$. Such socio-economic differentials in exposure and health risk can be characterised as a source of environmental injustice, which exacerbates health inequalities via the 'triple jeopardy' of low SEP, polluted environment and impaired health ${ }^{12,17,18}$.

In air pollution epidemiology research studies, SEP is typically characterised using individual-level and/or small area-level markers. In the UK, a very commonly used small-area marker is the Index of Multiple Deprivation (IMD ${ }^{19}$ ), which is available at Super Output Area level (containing around 1500 people). The IMD is typically examined as a single summary index of deprivation, although it can also be disaggregated to look at different domains of deprivation. A second less common small-area marker is the ACORN classifier ('A geodemographic Classification system Of Residential Neighbourhoods ${ }^{20}$ ), which is available at the postcode level (containing around 50 people). To our knowledge, no previous study has compared the performance of these markers in terms of characterising and adjusting for SEP in epidemiological studies of air pollution and health. It is, however, plausible that they capture different aspects of socioeconomic influence. For example, ACORN has a finer geographic resolution than IMD, and also includes additional variables such as age, life stage (e.g. children's age, working vs. retired) and 'lifestyle'.

There is also relatively limited evidence on how well such area-level markers perform against individual-level markers of SEP. Many air pollution studies do not have access to 
individual-level SEP data, and this is frequently cited as a reason for caution in interpreting their findings. Only a few studies, however, have investigated the likely magnitude of residual confounding by individual SEP and also smoking ${ }^{21,22}$. These studies found limited additional value from inclusion of individual markers of SEP and smoking after making area-level adjustments.

This paper therefore uses data from London (UK) to 1) characterise in detail the association between air pollution and SEP, comparing different SEP markers and different scales of measurement; and 2) assess the potential for residual confounding in studies lacking individual-level data on SEP and smoking. This paper thereby addresses methodological issues of general relevance for studies investigating air pollution and health, as well as characterizing socio-economic inequalities which are of interest in their own right.

\section{$\underline{\text { Methods }}$}

\section{Setting and participants}

We focussed upon residential unit postcodes within the orbital M25 motorway of London (UK). These 7-digit postcodes are used for mail delivery and contain a mean of 14 households and 51 individuals. We excluded the 870 postcodes not classified by ACORN, leaving a total of 186424 postcodes in our analyses. The centroids of which were nested within 5344 Super Output Areas (SOAs) and 55 boroughs: SOAs contain a mean of around 1500 individuals and are the smallest areas for which census data are made available. For analytical purposes we also defined four zones of London: 'central London' ( $\leq 5 \mathrm{~km}$ from Charing Cross, London's conventional centre); 'inner London', (>5km from Charing Cross but in one of the 13 inner London boroughs); 'outer London' (the 20 outer London boroughs); and 'outside London' (the 22 boroughs outside Greater London but with postcodes inside the M25).

Our individual-level analyses used data from the Whitehall II study, an occupational cohort of London civil servants ${ }^{23}$. Out of 10,308 civil servants first recruited to the Whitehall study in 1985-1988, 6914 (67.1\%) participated in the Whitehall II phase 7 follow-up in 2002-2004. Of these, 3654 Phase 7 participants had current residential postcodes within the M25 and formed the study population for this paper. These 3654 individuals had a mean age of 60.6 years (range $50-74$ ) and were $64.0 \%$ male.

The study was approved by the London School of Hygiene and Tropical Medicine ethics committee, application number 5410.

\section{Modelled exposure to air pollution}

Annual average (2003) nitrogen oxides $\left(\mathrm{NO}_{\mathrm{x}}\right)$ concentrations were provided by the Environmental Research Group, King's College London. $\mathrm{NO}_{\mathrm{x}}$ was used as a surrogate for traffic-related air pollution because it showed more spatial variation within London than the other modelled pollutants $\left(\mathrm{PM}_{10}\right.$ and $\left.\mathrm{NO}_{2}\right)$. The modelling approach has been 
described previously ${ }^{16,24}$. Briefly, the $\mathrm{NO}_{\mathrm{x}}$ contribution for roadways within a $500 \mathrm{~m}$ buffer around 31 monitoring locations was modelled using ADMS Roads ${ }^{25}$ and OSPM ${ }^{26}$ and the contribution from the urban background was modelled using ADMS3. Concentrations from these emission-dispersion models were calibrated by fitting regression models to $\mathrm{NO}_{\mathrm{x}}$ measurements from the 31 monitoring sites. The regression model was then applied to predict $\mathrm{NO}_{\mathrm{x}}$ concentrations on a $20 \mathrm{mX} 20 \mathrm{~m}$ grid. Postcode average $\mathrm{NO}_{\mathrm{x}}$ was calculated by averaging the concentrations for all gridpoints within $25 \mathrm{~m}$ of the postcode centroid. The correlation between modelled and measured $\mathrm{NO}_{\mathrm{x}}$ concentrations was 0.6 at 23 monitoring locations not included in the calibration step.

\section{Markers of socio-economic position}

We used markers of SEP measured at three different scales: the SOA, the postcode and the individual.

\section{(i) Super Output Area-level Index of Multiple Deprivation (IMD)}

The Index of Multiple Deprivation IMD: ${ }^{27}$ is a weighted composite of small-area data relating to ten domains and subdomains (henceforth 'domains'): income; employment; health; child education; adult education; crime; barriers to housing; barriers to services; indoor environment; and outdoor environment. Data for these domains can also be analysed separately.

Because outdoor environment deprivation is partly based upon modelled concentration of nitrogen dioxide, benzene, sulphur dioxide and particulates, we created an 'IMD-minusoutdoor environment' score. We did this adapting an approach previously used to remove the health domain from the full IMD score ${ }^{28}$. As when calculating the full IMD score ${ }^{27}$, we standardized and exponentially transformed the non-outdoor environment domains. We then calculated new weights by reallocating the $3 \%$ weight of the outdoors environment score across the other domains, in proportion to their original weights (see Supplementary material).

(ii) Postcode-level ACORN classifier ('A Geodemographic Classification system of Residential Neighbourhoods')

The ACORN classification ${ }^{20}$ starts by categorising census output areas using data from the 2001 UK census. Lifestyle/consumer surveys and publically-available data are then used 1) to reclassify postcodes differing substantially from their surrounding area and 2) to update ACORN annually. In this paper we use the ACORN 2003 mid-level categorization of 17 'groups', ranked by ACORN in order of affluence (details in the Supplementary material).

(iii) Individual-level SEP and smoking status from the Whitehall II cohort

Participants in Phase 7 of the Whitehall II cohort ${ }^{23}$ provided their current/most recent employment grade at the civil service, classified as clerical/executive officer (lower); 
Higher/Senior executive officer (intermediate); and unified grades 1-7 (higher).

Participants also provided information on their highest educational attainment, current household income and smoking habits. We also used the participants' current residential postcodes to assign the NOx, IMD and ACORN measures described above.

\section{Statistical analysis}

Analyses focused on the association between $\mathrm{NO}_{\mathrm{x}}$ concentrations and the various markers of SEP, analysed by tabulation and linear regression. $\mathrm{As}_{\mathrm{NO}_{\mathrm{x}}}$ concentrations were positively skewed, we used $\log \mathrm{NO}_{\mathrm{x}}$ values as the outcome in regression analyses. For ease of interpretation, we converted the regression coefficients $(\beta \mathrm{s})$ into percent increase for unit change in explanatory factor using the formula $[\exp (\beta)-1]^{*} 100$. We standardized all IMD scores using the London-wide means and standard deviations.

We accounted for spatial autocorrelation by fitting three-level random intercept models, of postcodes (or individuals) nested within SOAs nested within boroughs:

$$
\mathrm{Y}_{\mathrm{ijk}}=\beta_{0}+\beta_{1} \mathrm{x}_{1 \mathrm{ijk}}+\ldots+\beta_{\mathrm{p}} \mathrm{x}_{\mathrm{pijk}}+\mathrm{B}_{\mathrm{k}}+\mathrm{S}_{\mathrm{jk}}+\mathrm{e}_{\mathrm{ijk}}
$$

Where $\mathrm{Y}_{\mathrm{ijk}}$ is the modelled $\mathrm{NO}_{\mathrm{x}}$ concentration for the $i$ th postcode/individual in the $j$ th SOA in the $k$ th borough; $\beta_{1} \ldots \beta_{\mathrm{p}}$ are the parameters for the fixed effects of interest $\left(\mathrm{x}_{1 \mathrm{ijk} . . .} \mathrm{x}_{\mathrm{pijk}}\right)$, for example different ACORN groups; $\mathrm{B}_{\mathrm{k}}$ is a random intercept for $\mathrm{NO}_{\mathrm{x}}$ levels in the $k$ th borough; $S_{\mathrm{jk}}$ is a random intercept for $\mathrm{NO}_{\mathrm{x}}$ in the $j$ th $\mathrm{SOA}$ in the $k$ th borough; and $\mathrm{e}_{\mathrm{ijk}}$ is the residual error term. Random intercepts were assumed to be normally distributed, allowing for different variance parameters for each random intercept and the residual error and were estimated using maximum likelihood estimation. We quantified spatial autocorrelation in $\mathrm{NO}_{\mathrm{x}}$ using intraclass correlation coefficients (between-group variance/total variance), with the between-group variance equal to the variance of that level plus all higher levels. We also present $\mathrm{R}^{2}$ values calculated as the percent reduction in each component of the model variance, as compared to the model without any covariates.

Among Whitehall II participants, the frequency of missing covariate data was $0-14.7 \%$. We used multiple imputation to impute missing values under an assumption of missing at random, combining estimates across imputation models ${ }^{29}$. We used five imputations for these models, including in our imputation models all explanatory and outcome variables used in our models. We conducted statistical analyses in Stata 11.0, and created maps using ArcGIS.

\section{$\underline{\text { Results }}$}

\section{Air pollution and area deprivation}

$\mathrm{NO}_{\mathrm{x}}$ concentrations generally fell steadily at increasing distance from central London, from a mean of 136 parts per billion (range 88 to 415 ) in the $2 \mathrm{~km}$ around Charing Cross to 40-60 parts per billion on the outskirts (Error! Reference source not found.; graphs 
for IMD in the Supplementary material). There was substantial spatial autocorrelation in $\mathrm{NO}_{\mathrm{x}}$ concentrations. In a model without any covariates, the correlation between the $\mathrm{NO}_{\mathrm{x}}$ concentrations of postcodes in the same borough but different SOAs was 0.66, and the correlation between postcodes in the same SOA was 0.77. As shown in Error!

Reference source not found., accounting for this autocorrelation substantially increased the standard errors and simultaneously decreased the effect sizes of the IMD scores.

Allowing for spatial autocorrelation, each standard deviation (SD) increase in the full IMD score was associated with a $2.7 \%$ increase in $\mathrm{NO}_{\mathrm{x}}$ concentration (95\% CI 2.3 to 3.1; see also Error! Reference source not found.). When repeated using the IMD-minusoutdoor-environment score, however, this attenuated to a $1.6 \%$ increase in $\mathrm{NO}_{\mathrm{x}}(95 \% \mathrm{CI}$ 1.2 to 2.0), suggesting that the inclusion of an air quality indicator within the IMD introduced substantial circularity when examining its association with air pollution. Notably, the simple linear regression analysis which ignored both this circularity and the spatial autocorrelation produced an effect estimate which was an order of magnitude too large (13.4\% vs. $1.6 \%)$.

Figure 1: Smoothed postcode averages for traffic-related air pollution $\left(\mathrm{NO}_{\mathrm{x}}\right)$ across Greater London.

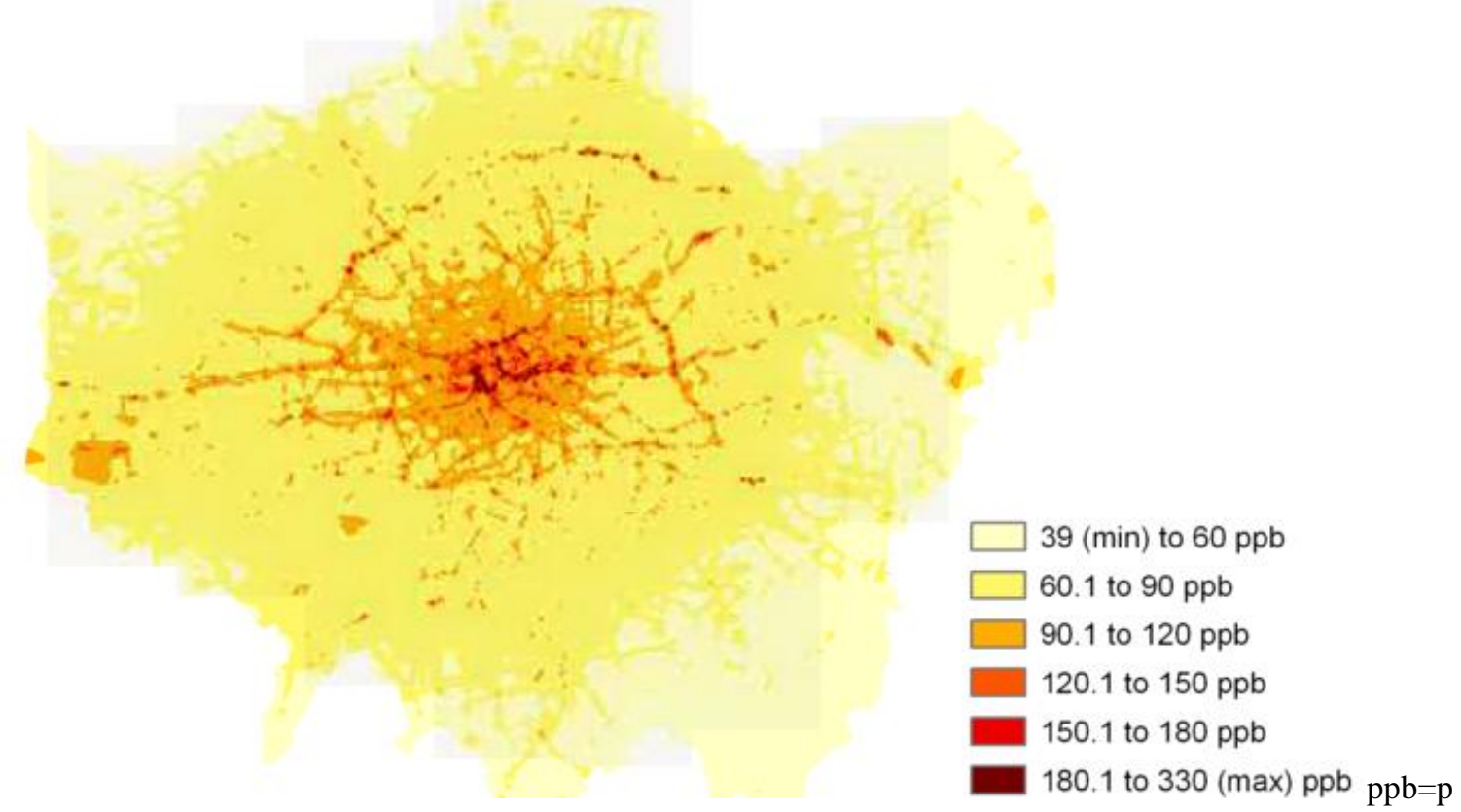

arts per billion. Postcode average $\mathrm{NO}_{\mathrm{x}}$ concentrations were smoothed using ordinary kriging and an exponential semivariogram model. 
Figure 2: Percent increase in $\mathrm{NO}_{\mathrm{x}}$ concentrations by the full IMD and ACORN scores, in residential postcodes in London ( $\mathrm{N}=186$ 424)
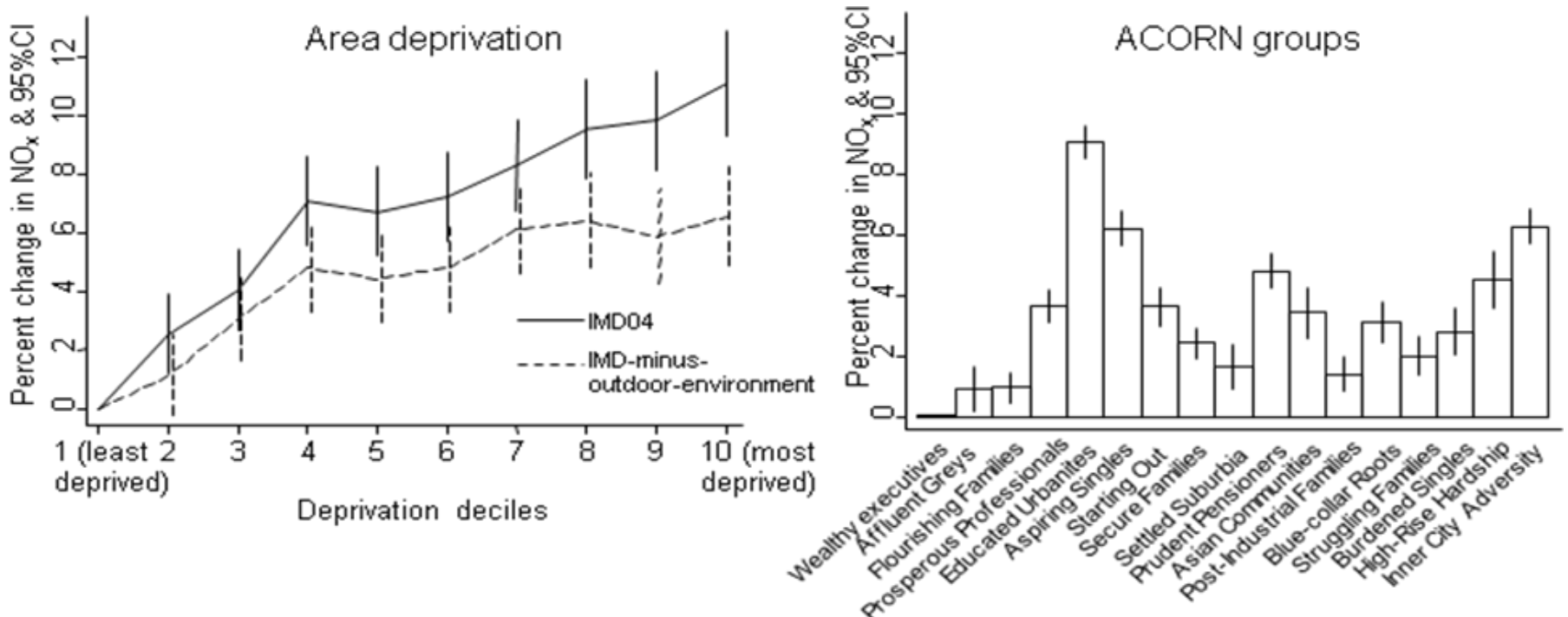

Our subsequent analyses focussed upon the separate IMD domains. The Pearson correlations between these domains was usually below 0.75 (see Supplementary material), with the exception of values $>0.85$ between income, employment and health.

The strength of association with $\mathrm{NO}_{\mathrm{x}}$ concentrations showed appreciable variation by domain. This included a negative association for adult education and barriers to services, i.e. areas with greater deprivation in these respects had less air pollution; comparatively weak positive associations for child education and income, and appreciably stronger positive associations for outdoor environment and housing (Error! Reference source not found.). These associations were all approximately linear (graphs in Supplementary material) and persisted in multivariable analyses, albeit often with some attenuation of effect sizes (Error! Reference source not found. column 1). 
Table 1: Association (unadjusted) between $\mathrm{NO}_{\mathrm{x}}$ concentrations and the 2004 IMD score and its component domains for 186,424 postcodes of London

\begin{tabular}{|l|c|c|}
\hline & \multicolumn{2}{|l|}{$\begin{array}{l}\text { Percent increase (95\% CI) in NO } \\
\text { concentration per standard deviate increase in } \\
\text { explanatory variable }\end{array}$} \\
\hline & $\begin{array}{l}\text { Without adjustment } \\
\text { for spatial auto- } \\
\text { correlation }\end{array}$ & $\begin{array}{l}\text { Allowing for spatial } \\
\text { auto-correlation } \dagger\end{array}$ \\
\hline & & \\
\hline Full IMD score (z-score) & $13.6(13.4,13.7)$ & $2.7(2.3,3.2)$ \\
IMD-minus-outdoor-environment & $11.5(11.3,11.6)$ & $1.6(1.2,2.0)$ \\
(z-score) & $6.7(6.6,6.9)$ & $1.1(0.8,1.5)$ \\
\hline Income (z-score) & $8.1(8.0,8.3)$ & $1.5(1.1,1.8)$ \\
Employment (z-score) & $10.2(10.1,10.3)$ & $2.5(2.0,3.0)$ \\
Health (z-score) & $7.8(7.6,7.9)$ & $1.1(0.7,1.5)$ \\
Education: child (z-score) & $-11.9(-12.0,-11.8)$ & $-2.2(-2.5,-1.8)$ \\
Education: adult (z-score) & $8.5(8.3,8.6)$ & $3.5(3.1,3.8)$ \\
Crime (z-score) & $24.9(24.8,25.1)$ & $13.1(12.1,14.2)$ \\
Barriers: housing (z-score) & $-15.1(-15.2,-15.0)$ & $-3.0(-3.4,-2.7)$ \\
Barriers: service (z-score) & $19.7(19.6,19.9)$ & $4.7(4.3,5.1)$ \\
Environment: indoor (z-score) & $26.6(26.5,26.7)$ & $10.6(10.1,11.0)$ \\
Environment: outdoor (z-score) & & \\
\hline
\end{tabular}

$\dagger$ We adjusted for spatial autocorrelation using a three level random intercept model in which postcodes were nested within SOAs which were nested in boroughs. 
Table 2: Percent increase in $\mathrm{NO}_{\mathrm{x}}$ concentrations in relation to IMD domain $\mathrm{z}$-scores and ACORN group.

\begin{tabular}{|c|c|c|c|c|c|}
\hline & & & \multicolumn{3}{|c|}{$\begin{array}{l}\text { Percent increase }(95 \% \mathrm{CI}) \text { in } \mathrm{NO}_{\mathrm{x}} \text { per unit increase in value } \\
\text { in explanatory factor }\end{array}$} \\
\hline & & $\begin{array}{l}\text { N } \\
\text { postcodes }\end{array}$ & IMD domains $\dagger$ & ACORN group & $\begin{array}{l}\text { Model containing } \\
\text { both IMD domains } \\
+ \text { ACORN group } \$\end{array}$ \\
\hline $\begin{array}{l}\text { IMD } \\
\text { domains } \\
\text { (z-scores) }\end{array}$ & $\begin{array}{l}\text { Employment } \\
\text { Education: child } \\
\text { Education: adult } \\
\text { Crime } \\
\text { Barriers: housing } \\
\text { Barriers: service } \\
\text { Environment: indoor }\end{array}$ & $\begin{array}{l}186424 \\
186424 \\
186424 \\
186424 \\
186424 \\
186424 \\
186424 \\
\end{array}$ & $\begin{array}{c}1.3(0.8,1.8) \\
0.5(0.1,1.0) \\
-5.1(-5.6,-4.6) \\
1.9(1.5,2.3) \\
11.1(9.8,12.5) \\
-1.3(-1.7,-1.0) \\
1.3(0.9,1.7) \\
\end{array}$ & & $\begin{array}{c}1.1(0.6,1.6) \\
0.1(-0.4,0.6) \\
-3.8(-4.3,-3.3) \\
1.8(1.4,2.1) \\
9.7(8.4,11.0) \\
-1.2(-1.6,-0.9) \\
0.8(0.4,1.2) \\
\end{array}$ \\
\hline $\begin{array}{l}\text { ACORN } \\
\text { group }\end{array}$ & $\begin{array}{l}\text { Wealthy executives } \\
\text { Affluent Greys } \\
\text { Flourishing Families } \\
\text { Prosperous Professionals } \\
\text { Educated Urbanites } \\
\text { Aspiring Singles } \\
\text { Starting Out } \\
\text { Secure Families } \\
\text { Settled Suburbia } \\
\text { Prudent Pensioners } \\
\text { Asian Communities } \\
\text { Post-Industrial Families } \\
\text { Blue-collar Roots } \\
\text { Struggling Families } \\
\text { Burdened Singles } \\
\text { High-Rise Hardship } \\
\text { Inner City Adversity }\end{array}$ & $\begin{array}{c}9184 \\
2131 \\
7675 \\
9455 \\
59238 \\
17934 \\
4730 \\
19411 \\
2288 \\
5446 \\
2662 \\
8162 \\
4004 \\
6431 \\
2382 \\
1261 \\
24030 \\
\end{array}$ & & $\begin{array}{c}0 \\
0.9(0.2,1.7) \\
1.0(0.5,1.5) \\
3.6(3.1,4.2) \\
9.1(8.5,9.6) \\
6.2(5.7,6.8) \\
3.6(3.0,4.3) \\
2.4(1.9,2.9) \\
1.7(0.9,2.4) \\
4.8(4.2,5.4) \\
3.4(2.6,4.3) \\
1.4(0.8,2.0) \\
3.1(2.5,3.8) \\
2.0(1.4,2.6) \\
2.8(2.1,3.6) \\
4.5(3.6,5.5) \\
6.3(5.7,6.8) \\
\end{array}$ & $\begin{array}{c}0 \\
0.9(0.2,1.6) \\
1.0(0.5,1.5) \\
3.0(2.5,3.6) \\
8.1(7.5,8.6) \\
5.5(5.0,6.1) \\
3.1(2.5,3.8) \\
2.3(1.8,2.8) \\
1.7(0.9,2.5) \\
4.4(3.8,5.0) \\
2.7(1.9,3.6) \\
1.4(0.8,2.0) \\
2.9(2.2,3.6) \\
1.7(1.1,2.4) \\
2.3(1.6,3.1) \\
3.8(2.9,4.8) \\
5.4(4.8,6.0) \\
\end{array}$ \\
\hline $\begin{array}{l}\text { Model } \\
\text { components } \\
\text { of variance }\end{array}$ & $\begin{array}{l}\text { Level 3: Borough-level } \\
\text { Level 2: SOA-level } \\
\text { Level 1: Postcode-level }\end{array}$ & & $\begin{array}{l}0.01 \\
0.01 \\
0.02\end{array}$ & $\begin{array}{l}0.04 \\
0.01 \\
0.02\end{array}$ & $\begin{array}{l}0.01 \\
0.01 \\
0.02\end{array}$ \\
\hline $\begin{array}{l}\text { Intra-class } \\
\text { correlation }\end{array}$ & $\begin{array}{l}\text { Level 3: Within boroughs } \\
\text { Level 2: Within SOAs }\end{array}$ & & $\begin{array}{l}0.32 \\
0.54\end{array}$ & $\begin{array}{l}0.63 \\
0.77\end{array}$ & $\begin{array}{l}0.33 \\
0.55\end{array}$ \\
\hline $\begin{array}{l}R^{2} \text { (percent } \\
\text { of variance } \\
\text { explained) }\end{array}$ & $\begin{array}{l}\text { Total } \mathbf{R}^{2} \\
\text { Level 3: Borough level } \mathbf{R}^{2} \\
\text { Level 2: SOA level } \mathbf{R}^{2} \\
\text { Level 1: Postcode level } \mathbf{R}^{2}\end{array}$ & & $\begin{array}{l}0.55 \\
0.79 \\
0.24 \\
0.00\end{array}$ & $\begin{array}{l}0.13 \\
0.17 \\
0.10 \\
0.01\end{array}$ & $\begin{array}{l}0.55 \\
0.78 \\
0.25 \\
0.01\end{array}$ \\
\hline
\end{tabular}

$\mathrm{IMD}=$ Indices of Multiple Deprivation, SOA=Super Output Area. $\uparrow$ Results for individual domains are adjusted for all other variables shown in the column. Outdoor environment IMD domain not entered due to the circularity of using it to predict air pollution; income and health IMD domains omitted due to collinearity with IMD employment.

There was also strong evidence that these associations were not uniform across all zones of London ( $p<0.001$ for interaction between all 10 domains and zone of London except child education for which $\mathrm{p}=0.08$; full results in Supplementary material). Point estimates of positive or negative associations were generally largest in outer London, usually followed by inner London. Outside London the associations were weaker or nonsignificant while in central London most associations were non-significant or in the reverse direction; that is, in central London higher SEP was associated with higher $\mathrm{NO}_{\mathrm{x}}$ 
concentrations. The overall positive association between the full IMD score and air pollution therefore concealed heterogeneity both by deprivation type and across different zones of the city.

\section{ACORN as a complementary socioeconomic indicator at the postcode level}

We next examined the potential of ACORN to substitute or complement IMD. There was strong evidence of heterogeneity in $\mathrm{NO}_{\mathrm{x}}$ exposure across the ACORN groups (Error! Reference source not found. and Error! Reference source not found.). The lowest $\mathrm{NO}_{\mathrm{x}}$ exposure was for 'Wealthy executives', the most affluent ACORN group (rank 1/17). Unlike for IMD, however, air pollution did not then show a progressive association with ACORN rank. For example, the groups with the highest $\mathrm{NO}_{\mathrm{x}}$ concentrations were 'Educated urbanites' (rank 5/17; $\mathrm{NO}_{\mathrm{x}}$ exposure $9.08 \%$ higher than Wealthy executives) followed by 'Inner city adversity' (rank 17/17) and 'Aspiring singles' (rank 6/17). It was also notable that the 17 ACORN groups had a Spearman's correlation of only 0.45 with the IMD deciles. This low correlation reflected comparatively high IMD scores in groups like 'Educated urbanites', 'Aspiring singles' and 'Asian communities' (see Supplementary material).

The IMD and ACORN effect sizes decreased relatively modestly in multivariable analyses including both markers simultaneously (Error! Reference source not found. column 3). Both markers likewise independently predicted $\mathrm{NO}_{\mathrm{x}}$ concentrations in analyses stratified by zone of London (see Supplementary material). ACORN's finer geographic resolution also meant that although overall it explained less $\mathrm{NO}_{\mathrm{x}}$ variance than IMD $\left(\mathrm{R}^{2}=0.13\right.$ for $\mathrm{ACORN}, \mathrm{R}^{2}=0.55$ for IMD), it did uniquely explain a small part of the residual variation at the postcode level $\left(R^{2}=0.01\right.$ for ACORN, $R^{2}=0.00$ for IMD).

\section{Low potential for residual confounding by individual-level characteristics}

IMD and ACORN were associated with all individual-level SEP and smoking variables in the Whitehall II cohort, with stronger associations for ACORN (see Supplementary material). In (unadjusted) analyses of the individual-level Whitehall II data, $\mathrm{NO}_{\mathrm{x}}$ exposure was associated with low employment grade, low household income and current smoking ( $\mathrm{p}<0.002$ for heterogeneity) but not with highest education $(\mathrm{p}>0.6$; see also Error! Reference source not found.). Nevertheless the differences in $\mathrm{NO}_{\mathrm{x}}$ concentration across the fairly broad categories of each of these variables were modest (mainly less than 2\%). This was substantially smaller than the differences of up to around $20 \%$ per standard deviate change in IMD domain or the variation across ACORN groups (Table 3). Moreover, adjusting for these area-level markers caused the individuallevel associations to become only weakly significant for smoking ( $\mathrm{p}=0.02$ for heterogeneity) and non-significant for $\mathrm{SEP}(\mathrm{p} \geq 0.06$ for heterogeneity). 
Table 3: Percent increase in $\mathrm{NO}_{\mathrm{x}}$ concentration in relation to SEP and smoking, with and without adjustment for IMD domains and ACORN

\begin{tabular}{|c|c|c|c|c|c|c|c|c|}
\hline & & & \multirow{3}{*}{$\begin{array}{l}\text { Number of } \\
\text { individuals }\end{array}$} & \multicolumn{5}{|c|}{ Percent increase $(95 \% \mathrm{CI})$ in $\mathrm{NO}_{\mathrm{x}}$} \\
\hline & & & & \multirow[t]{2}{*}{ Unadjusted } & \multicolumn{4}{|l|}{ Adjusted for } \\
\hline & & & & & $\begin{array}{l}\text { Individual-level } \\
\text { factors only }\end{array}$ & $\begin{array}{l}\text { Individual- } \\
\text { level factors } \\
\text { plus ACORN }\end{array}$ & $\begin{array}{l}\text { Individual-level } \\
\text { factors plus IMD }\end{array}$ & $\begin{array}{l}\text { Individual-level } \\
\text { factors plus IMD } \\
\text { and ACORN }\end{array}$ \\
\hline \multirow{4}{*}{$\begin{array}{l}\text { Individual } \\
\text {-level } \\
\text { markers }\end{array}$} & Grade & $\begin{array}{l}\text { Lower } \\
\text { Intermediate } \\
\text { Higher }\end{array}$ & $\begin{array}{l}1123 \\
1054 \\
1412\end{array}$ & $\begin{array}{c}0 \\
-1.1(-1.9,-0.3) \\
-1.7(-2.5,-0.9)\end{array}$ & $\begin{array}{c}0 \\
-1.1(-1.9,-0.2) \\
-1.6(-2.6,-0.6)\end{array}$ & $\begin{array}{c}0 \\
-1.0(-1.9,-0.1) \\
-1.5(-2.4,-0.5)\end{array}$ & $\begin{array}{c}0 \\
-0.8(-1.7,0.0) \\
-1.2(-2.1,-0.2)\end{array}$ & $\begin{array}{c}0 \\
-0.8(-1.6,0.0) \\
-1.1(-2.1,-0.2)\end{array}$ \\
\hline & $\begin{array}{l}\text { Highest } \\
\text { education }\end{array}$ & $\begin{array}{l}\text { None } \\
\text { O-levels } \\
\text { A/S level } \\
\text { BA/BSc } \\
\text { Postgraduate }\end{array}$ & $\begin{array}{l}357 \\
797 \\
805 \\
716 \\
442 \\
\end{array}$ & $\begin{array}{c}0 \\
0.2(-1.0,1.4) \\
-0.4(-1.6,0.7) \\
-0.5(-1.7,0.8) \\
-0.3(-1.6,1.1) \\
\end{array}$ & $\begin{array}{c}0 \\
0.6(-0.6,1.8) \\
0.5(-0.7,1.7) \\
0.8(-0.6,2.2) \\
1.2(-0.2,2.7)\end{array}$ & $\begin{array}{c}0 \\
0.7(-0.6,2.0) \\
0.5(-0.7,1.7) \\
0.8(-0.6,2.3) \\
1.5(0.0,3.0) \\
\end{array}$ & $\begin{array}{c}0 \\
0.4(-0.8,1.6) \\
0.0(-1.2,1.1) \\
0.2(-1.1,1.6) \\
0.6(-0.9,2.1) \\
\end{array}$ & $\begin{array}{c}0 \\
0.5(-0.8,1.7) \\
0.1(-1.0,1.3) \\
0.4(-1.0,1.8) \\
1.0(-0.5,2.5)\end{array}$ \\
\hline & $\begin{array}{l}\text { Household } \\
\text { income } \\
\text { last year }\end{array}$ & $\begin{array}{l}<£ 20000 \\
£ 20000-34999 \\
£ 35000-64999 \\
\geq £ 70000\end{array}$ & $\begin{array}{c}869 \\
935 \\
1062 \\
504 \\
\end{array}$ & $\begin{array}{c}0 \\
-0.1(-1.0,0.7) \\
-1.4(-2.2,-0.5) \\
-1.2(-2.2,-0.2) \\
\end{array}$ & $\begin{array}{c}0 \\
0.2(-0.6,1.1) \\
-0.9(-1.8,0.0) \\
-0.5(-1.7,0.6) \\
\end{array}$ & $\begin{array}{c}0 \\
0.5(-0.4,1.3) \\
-0.4(-1.3,0.5) \\
0.1(-1.1,1.2) \\
\end{array}$ & $\begin{array}{c}0 \\
0.3(-0.6,1.1) \\
-0.8(-1.7,0.1) \\
-0.6(-1.7,0.6) \\
\end{array}$ & $\begin{array}{c}0 \\
0.4(-0.4,1.3) \\
-0.6(-1.4,0.3) \\
-0.2(-1.3,0.9) \\
\end{array}$ \\
\hline & Smoking & $\begin{array}{l}\text { Never } \\
\text { Ex-smoker } \\
\text { Current smoker }\end{array}$ & $\begin{array}{c}1881 \\
1389 \\
345 \\
\end{array}$ & $\begin{array}{c}0 \\
-0.2(-0.8,0.5) \\
1.9(0.8,3.0)\end{array}$ & $\begin{array}{c}0 \\
0.0(-0.7,0.6) \\
1.9(0.8,3.0)\end{array}$ & $\begin{array}{c}0 \\
0.1(-0.5,0.7) \\
1.5(0.4,2.6)\end{array}$ & $\begin{array}{c}0 \\
0.0(-0.6,0.6) \\
1.6(0.6,2.7)\end{array}$ & $\begin{array}{c}0 \\
0.0(-0.6,0.6) \\
1.5(0.4,2.6)\end{array}$ \\
\hline $\begin{array}{l}\text { Postcode- } \\
\text { level } \\
\text { markers }\end{array}$ & $\begin{array}{l}\text { ACORN } \\
\text { group }\end{array}$ & $\begin{array}{l}\text { Wealthy executives } \\
\text { Affluent Greys } \\
\text { Flourishing Families } \\
\text { Prosperous Professionals } \\
\text { Educated Urbanites } \\
\text { Aspiring Singles } \\
\text { Starting Out } \\
\text { Secure Families } \\
\text { Settled Suburbia } \\
\text { Prudent Pensioners } \\
\text { Asian Communities } \\
\text { Post-Industrial Families } \\
\text { Blue-collar Roots } \\
\text { Struggling Families }\end{array}$ & $\begin{array}{c}302 \\
62 \\
301 \\
386 \\
832 \\
285 \\
104 \\
504 \\
74 \\
114 \\
30 \\
167 \\
54 \\
46 \\
\end{array}$ & $\begin{array}{c}0 \\
0.4(-2.2,3.1) \\
1.6(0.0,3.2) \\
6.3(4.5,8.1) \\
13.4(11.5,15.3) \\
8.2(6.1,10.3) \\
8.3(5.9,10.7) \\
4.0(2.4,5.7) \\
1.0(-1.5,3.5) \\
4.7(2.4,7.0) \\
7.6(2.7,12.8) \\
3.9(1.7,6.1) \\
7.2(4.0,10.5) \\
0.7(-2.8,4.2)\end{array}$ & & $\begin{array}{c}0 \\
0.4(-2.2,3.1) \\
1.6(0.0,3.2) \\
6.2(4.5,8.0) \\
13.2(11.3,15.1) \\
7.6(5.5,9.8) \\
8.0(5.6,10.4) \\
3.8(2.1,5.5) \\
0.6(-1.8,3.2) \\
4.4(2.1,6.8) \\
6.9(2.0,12.0) \\
3.6(1.4,5.7) \\
6.9(3.7,10.2) \\
0.2(-3.3,3.7)\end{array}$ & & $\begin{array}{c}0 \\
0.2(-2.5,3.0) \\
1.3(-0.3,2.9) \\
2.8(1.1,4.6) \\
7.1(5.2,9.1) \\
3.2(1.0,5.3) \\
4.4(2.1,6.9) \\
2.8(1.1,4.6) \\
0.5(-2.0,3.1) \\
2.1(-0.2,4.5) \\
3.0(-1.8,7.9) \\
2.7(0.5,5.0) \\
5.0(1.8,8.3) \\
-1.6(-5.1,2.1)\end{array}$ \\
\hline
\end{tabular}




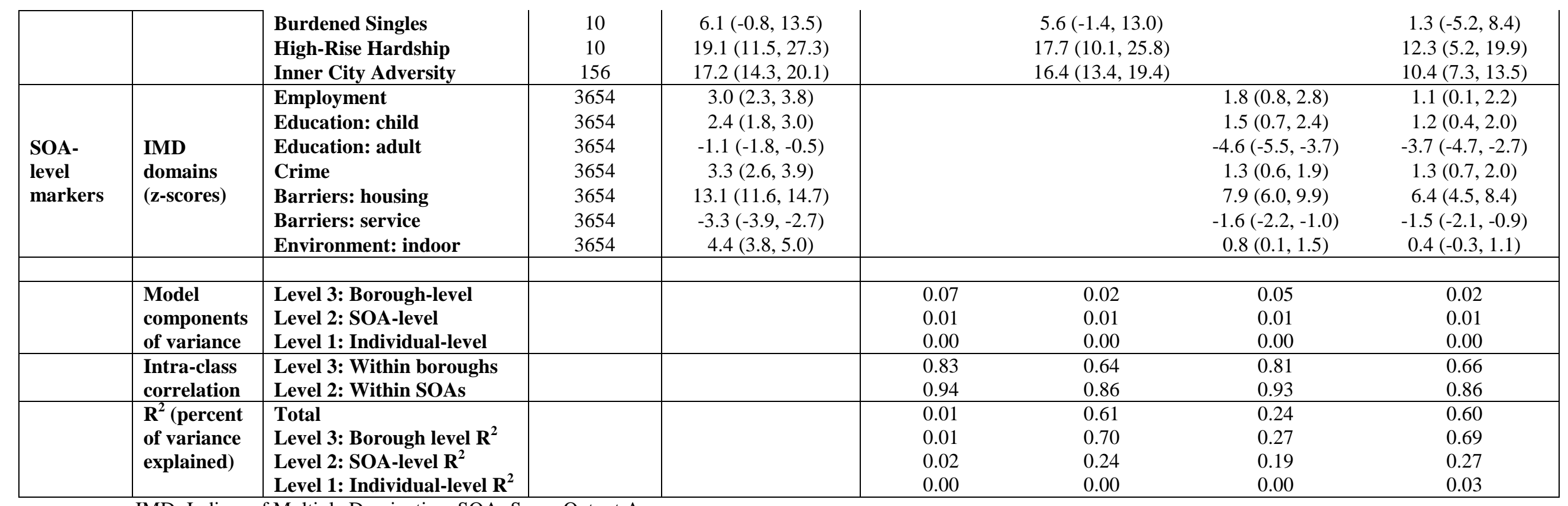

IMD=Indices of Multiple Deprivation, SOA=Super Output Area. 


\section{$\underline{\text { Discussion }}$}

This paper confirms an important substantive issue of environmental justice: across London as a whole, mean air pollution (as reflected in $\mathrm{NO}_{\mathrm{x}}$ concentrations) is greater for areas and individuals with lower socio-economic position/greater deprivation. The magnitude of the association was substantially over-estimated, however, by ignoring spatial autocorrelation in $\mathrm{NO}_{\mathrm{x}}$ and by ignoring the inclusion of an 'air quality' indicator in the full IMD score. This overall association also concealed heterogeneity by geographical zone and by type of SEP, including reversed directions of association in central London and for SEP markers related to adult education. In models including multiple SEP markers, air pollution was independently predicted by both the IMD zscores and the 17-group ACORN classifications. This indicates that ACORN may be a useful area-based complement to IMD in air pollution epidemiology studies seeking to adjust for sociodemographic characteristics. By contrast, $\mathrm{NO}_{\mathrm{x}}$ variation was relatively small across the (comparatively broad) markers of individual-level SEP status, and after adjusting for area-based markers there was little evidence of the potential for residual confounding by individual-level SEP and smoking. This suggests that finely-categorized area markers of deprivation show clearer association with air pollution than broad SEP groupings based on individual data. It further suggests that there is little disadvantage in lacking such individual-level markers of SEP for studies of air pollution and health which have good small-area data.

Our study replicates the recent demonstration that ignoring spatial autocorrelation substantially overestimated the magnitude of socio-economic inequalities in air pollution exposure ${ }^{30}$ Our study also demonstrates that the association between area SEP and air pollution was substantially overestimated by the inclusion of an 'air quality' indicator within the IMD scores released by the government in $2004^{19}$ and $2007^{31}$. This circularity may have led to overestimation of the association between SEP and air pollution in British studies using these IMD scores ${ }^{14,16}$. We therefore recommend that air pollution epidemiology studies enter the IMD domains separately, excluding the outdoor environment domain and also the health domain, as previously acknowledged ${ }^{28,32}$. We further recommend considering ACORN as a second complementary marker, given that ACORN was independently associated with $\mathrm{NO}_{\mathrm{x}}$, unlike IMD, explained some of the smallest scale variation that is most likely to cause residual confounding by individual SEP.

In investigating whether IMD and ACORN are likely to provide adequate adjustment for confounding by SEP, our analysis of the Whitehall II data revealed that traffic-related air pollution was more closely related to area-level than individual-level SEP. Moreover, adjusting for IMD and ACORN eliminated much of the relationship with individual SEP and smoking, a finding consistent with previous research ${ }^{21,22}$. This stronger association with area-level markers may partly reflect their finer categorisation; for example 17 ACORN groups vs. 3-5 categories for our individual-level SEP markers. While in this sense we were not comparing like with like, in practice few epidemiological studies have detailed data beyond relatively broad categorisations of individual SEP. Our findings suggest that air pollution epidemiology studies without individuallevel data of this sort are unlikely to suffer substantial residual confounding if they use comprehensive area-level adjustment. 
Yet even comprehensive area-level adjustment is unlikely to account fully for the multiple systematic differences in values and preferences which influence where people live. The sociodemographic and socio-economic characteristics we considered are probably among the most important differences for health, but do not capture all differences. For example, neighbourhoods in London with comparable levels of economic capital may have very different levels of social capital $^{33}$. Like most studies, we lacked area-level data on characteristics such as this, and therefore cannot estimate the magnitude of this additional residual confounding in air pollution epidemiology studies. Another limitation is our use of $\mathrm{NO}_{\mathrm{x}}$ concentration at the residential postcode as a surrogate for personal exposure to traffic related air pollution. This ignores potential socio-economic differences in activity patterns, time spent at residence or occupational exposure (although variability in the latter may have been reduced by our use of an occupational cohort).

Finally, it is unclear how far our substantive findings are generalisable outside of London. For example, disaggregating the 'child education' and 'adult education' IMD domains revealed that air pollution levels were higher in areas with many skilled adults, an anomaly consistent with the fact that 'Educated urbanites' were the most exposed ACORN group. Educational attainment was likewise the only individual-level SEP marker not associated with air pollution in Whitehall II. This distinctive association of education with air pollution has not previously been documented in the UK, and may not apply outside London - although consistent previous findings from Montreal ${ }^{34}$ suggest at least the potential for generalisability.

Yet even if these findings prove entirely context-specific, they illustrate several important general principles. First, air pollution may show different associations with different area- and individual-level SEP markers. Studies should therefore not assume that all dimensions of SEP can be used interchangeably when adjusting for confounding, and if possible should explore a range of SEP indicators. Second, the magnitude and even direction of the association with SEP may differ between geographical zones. Examining local socio-geographic contexts is therefore essential $^{34}$, and may also highlight opportunities for testing hypotheses using informative exceptions (e.g. affluent city centres exposed to high air pollution ${ }^{34,35}$ ).

In summary, small-area markers of socio-economic position appear to perform well in showing variations in exposure to traffic-related air pollution $\left(\mathrm{NO}_{\mathrm{x}}\right)$ and in allowing adjustment for confounding by socio-economic status in environmental epidemiological studies of air pollution and health. The associations with air pollution may vary between different domains of SEP and between larger geographical zones. Further study of these associations will provide greater insights into the inequalities that arise from the interrelationship between air pollution, socioeconomic position and health.

\section{$\underline{\text { Acknowledgments }}$}

We thank Sean Beevers at the Environmental Research Group, King's College London for providing modelled $\mathrm{NO}_{\mathrm{x}}$ concentrations. We are also grateful to Judy Green for comments on draft versions of this manuscript. Funding was provided by the Economic and Social Research 
Council RES-064-27-0026. The funders had no role in the conduct of the research or preparation of the article.

\section{Competing interests}

None

\section{$\underline{\text { References }}$}

1. Pope CA, 3rd, Thun MJ, Namboodiri MM, et al. Particulate air pollution as a predictor of mortality in a prospective study of U.S. adults. Am J Respir Crit Care Med. Mar 1995;151(3 Pt 1):669-674.

2. Pope CA, 3rd, Burnett RT, Thun MJ, et al. Lung cancer, cardiopulmonary mortality, and long-term exposure to fine particulate air pollution. JAMA. Mar 6 2002;287(9):11321141.

3. Hoek G, Brunekreef B, Goldbohm S, Fischer P, van den Brandt PA. Association between mortality and indicators of traffic-related air pollution in the Netherlands: a cohort study. Lancet. Oct 19 2002;360(9341):1203-1209.

4. $\quad$ Finkelstein MM, Jerrett M, Sears MR. Traffic air pollution and mortality rate advancement periods. Am J Epidemiol. Jul 15 2004;160(2):173-177.

5. Krewski D, Burnett R, Goldberg M, et al. Reanalysis of the Harvard Six Cities Study and the American Cancer Society Study of Particulate Air Pollution and Mortality. Boston, MA: Health Effects Institute; 2000.

6. Peters A, von Klot S, Heier M, et al. Exposure to traffic and the onset of myocardial infarction. N Engl J Med. Oct 21 2004;351(17):1721-1730.

7. Tonne C, Melly S, Mittleman M, Coull B, Goldberg R, Schwartz J. A case-control analysis of exposure to traffic and acute myocardial infarction. Environ Health Perspect. Jan 2007;115(1):53-57.

8. Miller KA, Siscovick DS, Sheppard L, et al. Long-term exposure to air pollution and incidence of cardiovascular events in women. N Engl J Med. Feb 1 2007;356(5):447-458.

9. Nyberg F, Gustavsson P, Jarup L, et al. Urban air pollution and lung cancer in Stockholm. Epidemiology. Sep 2000;11(5):487-495.

10. Gauderman WJ, Vora H, McConnell R, et al. Effect of exposure to traffic on lung development from 10 to 18 years of age: a cohort study. Lancet. Feb 17 2007;369(9561):571-577.

11. Morgenstern V, Zutavern A, Cyrys J, et al. Respiratory health and individual estimated exposure to traffic-related air pollutants in a cohort of young children. Occup Environ Med. Jan 2007;64(1):8-16.

12. O'Neill MS, Jerrett M, Kawachi I, et al. Health, wealth, and air pollution: advancing theory and methods. Environ Health Perspect. Dec 2003;111(16):1861-1870.

13. Deguen S, Zmirou-Navier D. Social inequalities resulting from health risks related to ambient air quality--A European review. Eur J Public Health. Feb 2010;20(1):27-35.

14. Briggs D, Abellan JJ, Fecht D. Environmental inequity in England: small area associations between socio-economic status and environmental pollution. Soc Sci Med. Nov 2008;67(10):1612-1629. 
15. Pye S, Stedman J, Adams M, King K. Further analysis of NO2 and PM10 air pollution and social deprivation, A report produced for DEFRA, The National Assembly for Wales and The Northern Ireland Department of the Environment: Report AEAT/ENV/R/0865 AEA Technology Environment;2001.

16. Tonne C, Beevers S, Armstrong B, Kelly F, Wilkinson P. Air pollution and mortality benefits of the London Congestion Charge: spatial and socioeconomic inequalities. Occup Environ Med. Sep 2008;65(9):620-627.

17. Jerrett M, Burnett RT, Kanaroglou P, et al. A GIS-environmental justice analysis of particulate air pollution in Hamilton, Canada. Environment and Planning A. 2001;33:955973.

18. Northridge ME, Stover GN, Rosenthal JE, Sherard D. Environmental equity and health: understanding complexity and moving forward. Am J Public Health. Feb 2003;93(2):209214.

19. Noble M, Wright G, Dibben C, et al. Indices of Deprivation 2004. Report to the Office of the Deputy Prime Minister. London: Neighbourhood Renewal Unit; 2004.

20. CACI. The ACORN user guide. London: CACI; 2009.

21. Naess O, Piro FN, Nafstad P, Smith GD, Leyland AH. Air pollution, social deprivation, and mortality: a multilevel cohort study. Epidemiology. Nov 2007;18(6):686-694.

22. Wheeler BW, Ben-Shlomo Y. Environmental equity, air quality, socioeconomic status, and respiratory health: a linkage analysis of routine data from the Health Survey for England. J Epidemiol Community Health. Nov 2005;59(11):948-954.

23. Marmot M, Brunner E. Cohort Profile: the Whitehall II study. Int J Epidemiol. Apr 2005;34(2):251-256.

24. Tonne C, Beevers S, Kelly F, Jarup L, Wilkinson P, Armstrong BG. An approach for estimating the health effects of changes over time in air pollution: an illustration using cardio-respiratory hospital admissions in London. Occup Environ Med. Nov 122009.

25. CERC. ADMS Roads Users Guide, Version 2.0. Cambridge: Cambridge Environmental Research Consultants; 2003.

26. Berkowicz R. OSPM - A parameterised street pollution model. Environmental Monitoring and Assessment. 2000;65:323-331.

27. Office of the Deputy Prime Minister. The English Indices of deprivation 2004 (revised). 2004; http://www.communities.gov.uk/documents/communities/pdf/131209.pdf. Accessed 26 Feb 2008.

28. Adams J, White M. Removing the health domain from the Index of Multiple Deprivation 2004-effect on measured inequalities in census measure of health. J Public Health (Oxf). Dec 2006;28(4):379-383.

29. Van Buuren S, Boshuizen HC, Knook DL. Multiple imputation of missing blood pressure covariates in survival analysis. Statistics in Medicine. 1999;18:681-694.

30. Havard S, Deguen S, Zmirou-Navier D, Schillinger C, Bard D. Traffic-related air pollution and socioeconomic status: a spatial autocorrelation study to assess environmental equity on a small-area scale. Epidemiology. Mar 2009;20(2):223-230.

31. Noble M, McLennan D, Wilkinson K, Whitworth A, Barnes H, Dibben C. The English Indices of Deprivation 2007. London: Department for Communities and Local Government; 2008.

32. Briggs D, Fecht D, de Hoogh K. Census data issues for epidemiology and health risk assessment: experiences from the Small Area Health Statistics Unit. J Roy Stat Soc a Sta. 2007; 170:355-378. 
33. Butler T, Robson G. Social capital, gentrification and neighbourhood change in London: A comparison of three south London neighbourhoods. Urban Stud. Nov 2001;38(12):2145-2162.

34. Crouse DL, Ross NA, Goldberg MS. Double burden of deprivation and high concentrations of ambient air pollution at the neighbourhood scale in Montreal, Canada. Soc Sci Med. Sep 2009;69(6):971-981.

35. Forastiere F, Stafoggia M, Tasco C, et al. Socioeconomic status, particulate air pollution, and daily mortality: Differential exposure or differential susceptibility. Am J Ind Med. Mar 2007;50(3):208-216. 


\section{Characterising socio-economic inequalities in air pollution: Supplementary material}

Table 4: Domains and indicators of the English Indices of Multiple Deprivation, 2004

\begin{tabular}{|c|c|c|c|c|}
\hline Domain & $\begin{array}{l}\text { Sub- } \\
\text { domain }\end{array}$ & Indicator variables (year of collection) & $\begin{array}{c}\text { Original } \\
\text { weight }\end{array}$ & $\begin{array}{l}\text { Redis- } \\
\text { tributed } \\
\text { weight }\end{array}$ \\
\hline $\begin{array}{l}\text { Income } \\
\text { Deprivation }\end{array}$ & & $\begin{array}{l}\text { 1. Adults and children in Income Support households (2001). } \\
\text { 2. Adults and children in Income Based Job Seekers Allowance households (2001). } \\
\text { 3. Adults and children in Working Families Tax Credit households with equivalised } \\
\text { income (excl. housing benefits) below } 60 \% \text { of median before housing costs (2001). } \\
\text { 4. Adults and children in Disabled Person's Tax Credit households whose equivalised } \\
\text { income (excl. housing benefits) below } 60 \% \text { of median before housing costs (2001). } \\
\text { 5. National Asylum Support Service supported asylum seekers in England in receipt of } \\
\text { subsistence only and accommodation support (2002). }\end{array}$ & $22.5 \%$ & $23.2 \%$ \\
\hline $\begin{array}{l}\text { Employment } \\
\text { Deprivation }\end{array}$ & & $\begin{array}{l}\text { 6. Unemployment claimant count (JUVOS) of women aged 18-59 and men aged 18-64 } \\
\text { averaged over } 4 \text { quarters (2001). } \\
\text { 7. Incapacity Benefit claimants (women aged 18-59 and men aged 18-64) (2001). } \\
\text { 8. Severe Disablement Allowance claimants (women aged 18-59, men aged 18-64) } \\
\text { (2001). } \\
\text { 9. Participants in New Deal for } 18-24 \text { year olds not in the claimant count (2001). } \\
\text { 10. Participants in New Deal for } 25 \text { year olds not included in the claimant count (2001). } \\
\text { 11. Participants in New Deal for Lone Parents aged } 18 \text { and over (2001). }\end{array}$ & $22.5 \%$ & $23.2 \%$ \\
\hline $\begin{array}{l}\text { Health } \\
\text { Deprivation } \\
\text { and Disability }\end{array}$ & & $\begin{array}{l}\text { 12. Years of Potential Life Lost (1997-2001). } \\
\text { 13. Comparative Illness and Disability Ratio (2001). } \\
\text { 14. Measures of emergency admissions to hospital (1999-2002). } \\
\text { 15. Adults under } 60 \text { suffering from mood or anxiety disorders (1997-2002). }\end{array}$ & $13.5 \%$ & $13.9 \%$ \\
\hline \multirow[t]{2}{*}{$\begin{array}{l}\text { Education, } \\
\text { Skills and } \\
\text { Training } \\
\text { Deprivation }\end{array}$} & Child & $\begin{array}{l}\text { 16. Average points score of children at Key Stage } 2 \text { (2002). } \\
\text { 17. Average points score of children at Key Stage } 3(2002) \text {. } \\
\text { 18. Average points score of children at Key Stage } 4(2002) \text {. } \\
\text { 19. Proportion of young people not staying on in school or school level education above } \\
16 \text { (2001). } \\
\text { 20. Proportion of those aged under } 21 \text { not entering Higher Education (1999-2002). } \\
\text { 21. Secondary school absence rate (2001-2002). }\end{array}$ & $6.75 \%$ & $7.0 \%$ \\
\hline & Adult & $\begin{array}{l}\text { 22. Proportions of working age adults (aged 25-54) in the area with no or low } \\
\text { qualifications (2001). }\end{array}$ & $6.75 \%$ & $7.0 \%$ \\
\hline Crime & & $\begin{array}{l}\text { 23. Burglary (4 recorded crime offence types, April 2002-March 2003). } \\
\text { 24. Theft ( } 5 \text { recorded crime offence types, April 2002-March 2003, constrained to CDRP } \\
\text { level). } \\
\text { 25. Criminal damage ( } 10 \text { recorded crime offence types, April 2002-March 2003). } \\
\text { 26. Violence (14 recorded crime offence types, April 2002-March 2003). }\end{array}$ & $9.3 \%$ & $9.6 \%$ \\
\hline \multirow[t]{2}{*}{$\begin{array}{l}\text { Barriers to } \\
\text { Housing and } \\
\text { Services }\end{array}$} & Housing & $\begin{array}{l}\text { 27. Household overcrowding (2001). } \\
\text { 28. LA level percentage of households for whom a decision on their application for } \\
\text { assistance under the homeless provisions of housing legislation has been made, } \\
\text { assigned to SOAs ( } 2002) \text {. } \\
\text { 29. Difficulty of access to owner-occupation (2002). }\end{array}$ & $4.65 \%$ & $4.8 \%$ \\
\hline & $\begin{array}{l}\text { Distance } \\
\text { to } \\
\text { services }\end{array}$ & $\begin{array}{l}\text { 30. Road distance to GP premises (2003). } \\
\text { 31. Road distance to a supermarket or convenience store (2002). } \\
\text { 32. Road distance to a primary school (2001-2002). } \\
\text { 33. Road distance to a Post Office (2003). }\end{array}$ & $4.65 \%$ & $4.8 \%$ \\
\hline \multirow[t]{2}{*}{$\begin{array}{l}\text { The Living } \\
\text { Environment }\end{array}$} & Indoor & $\begin{array}{l}\text { 34. Social and private housing in poor condition (2001). } \\
\text { 35. Houses without central heating (2001). }\end{array}$ & $6.2 \%$ & $6.4 \%$ \\
\hline & Outdoor & $\begin{array}{l}\text { 36. Air quality [modelled concentration of Nitrogen Dioxide, Benzene, Sulphur Dioxide } \\
\text { and particulates] (2001). } \\
\text { 37. Road traffic accidents involving injury to pedestrians and cyclists (2000-2002). }\end{array}$ & $3.1 \%$ & $0 \%$ \\
\hline
\end{tabular}

Source: 1. Office of the Deputy Prime Minister. The English Indices of deprivation 2004 (revised), 2004. 
Table 5: ACORN categories, groups and types

\begin{tabular}{|c|c|c|}
\hline ACORN category & ACORN group & ACORN TYPE \\
\hline \multirow[t]{3}{*}{ Wealthy achievers } & Wealthy executives & $\begin{array}{l}\text { 1. Wealthy Mature Professionals, Large Houses } \\
\text { 2. Wealthy Working Families with Mortgages } \\
\text { 3. Villages with Wealthy Commuters } \\
\text { 4. Well-Off Managers, Larger Houses }\end{array}$ \\
\hline & Affluent Greys & $\begin{array}{ll}\text { 5. } & \text { Older Affluent Professionals } \\
\text { 6. } & \text { Farming Communities } \\
\text { 7. } & \text { Old People, Detached Homes } \\
\text { 8. } & \text { Mature Couples, Smaller Detached Homes }\end{array}$ \\
\hline & Flourishing Families & $\begin{array}{l}\text { 9. Older Families, Prosperous Suburbs } \\
\text { 10. Well-Off Working Families with Mortgage } \\
\text { 11. Well-Off Managers, Detached Houses } \\
\text { 12. Large Families and Houses in Rural Areas }\end{array}$ \\
\hline \multirow[t]{3}{*}{ Urban prosperity } & Prosperous Professionals & $\begin{array}{l}\text { 13. Well-Off Professionals, Larger Houses and Converted Flats } \\
\text { 14. Older Professionals in Suburban Houses and Apartments }\end{array}$ \\
\hline & Educated Urbanites & $\begin{array}{l}\text { 15. Affluent Urban Professionals, Flats } \\
\text { 16. Prosperous Young Professionals, Flats } \\
\text { 17. Young Educated Workers, Flats } \\
\text { 18. Multi-Ethnic Young, Converted Flats } \\
\text { 19. Suburban Privately Renting Professional }\end{array}$ \\
\hline & Aspiring Singles & $\begin{array}{l}\text { 20. Student Flats and Cosmopolitan Sharers } \\
\text { 21. Singles and Sharers, Multi-Ethnic Areas } \\
\text { 22. Low-Income Singles, Small Rented Flats } \\
\text { 23. Student Terraces }\end{array}$ \\
\hline \multirow[t]{4}{*}{ Comfortably off } & Starting Out & $\begin{array}{l}\text { 24. Young Couples, Flats and Terraces } \\
\text { 25. White-Collar Singles and Sharers, Terraces }\end{array}$ \\
\hline & Secure Families & $\begin{array}{l}\text { 26. Younger White-Collar Couples with Mortgages } \\
\text { 27. Middle-Income, Home-Owning Areas } \\
\text { 28. Working Families with Mortgages } \\
\text { 29. Mature Families in Suburban Semis } \\
\text { 30. Established Home-Owning Workers } \\
\text { 31. Home-Owning Asian Family Areas }\end{array}$ \\
\hline & Settled Suburbia & $\begin{array}{l}\text { 32. Retired Home Owners } \\
\text { 33. Middle-Income, Older Couples } \\
\text { 34. Lower Incomes, Older People, Semis }\end{array}$ \\
\hline & Prudent Pensioners & $\begin{array}{l}\text { 35. Elderly Singles, Purpose-Built Flats } \\
\text { 36. Older People, Flats }\end{array}$ \\
\hline \multirow[t]{3}{*}{ Moderate means } & Asian Communities & $\begin{array}{l}\text { 37. Crowded Asian Terraces } \\
\text { 38. Low-Income Asian Families }\end{array}$ \\
\hline & Post-Industrial Families & $\begin{array}{l}\text { 39. Skilled Older Families, Terraces } \\
\text { 40. Young Working Families }\end{array}$ \\
\hline & Blue-collar Roots & $\begin{array}{l}\text { 41. Skilled Workers, Semis and Terraces } \\
\text { 42. Home-Owning Families, Terraces } \\
\text { 43. Older People, Rented Terraces }\end{array}$ \\
\hline \multirow[t]{4}{*}{ Hard-pressed } & Struggling Families & $\begin{array}{l}\text { 44. Low-Income Larger Families, Semis } \\
\text { 45. Low-Income, Older People, Smaller Semis } \\
\text { 46. Low-Income, Routine Jobs, Terraces and flats } \\
\text { 47. Low-Income Families, Terraced Estates } \\
\text { 48. Families and Single Parents, Semis and terraces } \\
\text { 49. Large Families and Single Parents, Many children }\end{array}$ \\
\hline & Burdened Singles & $\begin{array}{l}\text { 50. Single Elderly People, Council Flats } \\
\text { 51. Single Parents and Pensioners, Council terraces } \\
\text { 52. Families and Single Parents, Council Flats }\end{array}$ \\
\hline & High-Rise Hardship & $\begin{array}{l}\text { 53. Old People, Many High-Rise Flats } \\
\text { 54. Singles and Single Parents, High-Rise Estates }\end{array}$ \\
\hline & Inner City Adversity & $\begin{array}{l}\text { 55. Multi-Ethnic, Purpose-Built Estates } \\
\text { 56. Multi-Ethnic, Crowded Flats }\end{array}$ \\
\hline
\end{tabular}

Source: CACI. The ACORN user guide. London: CACI, 2009. 
Figure 3: Distribution of the Index of Multiple Deprivation (IMD) score and domains across residential postcodes in London.

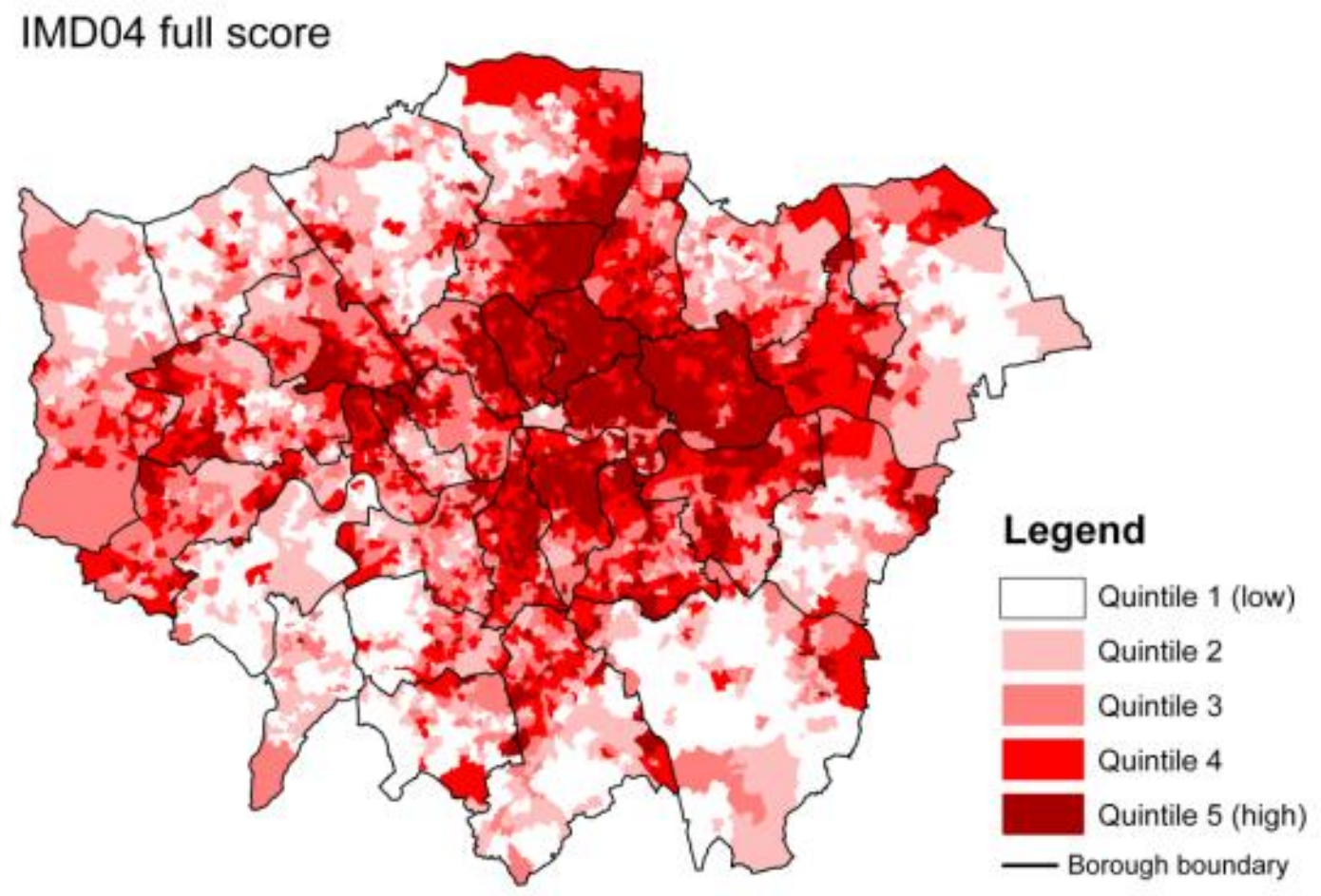

Income

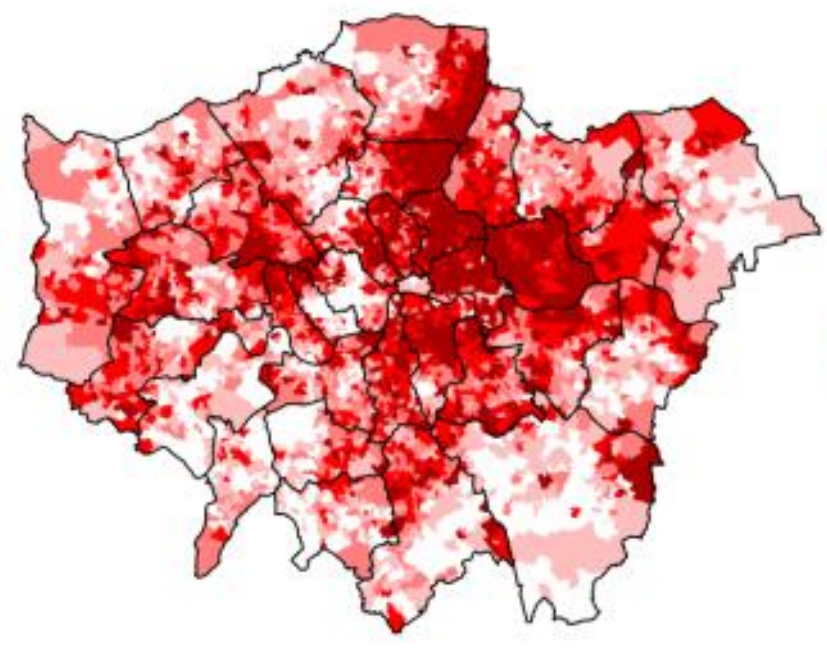

Employment

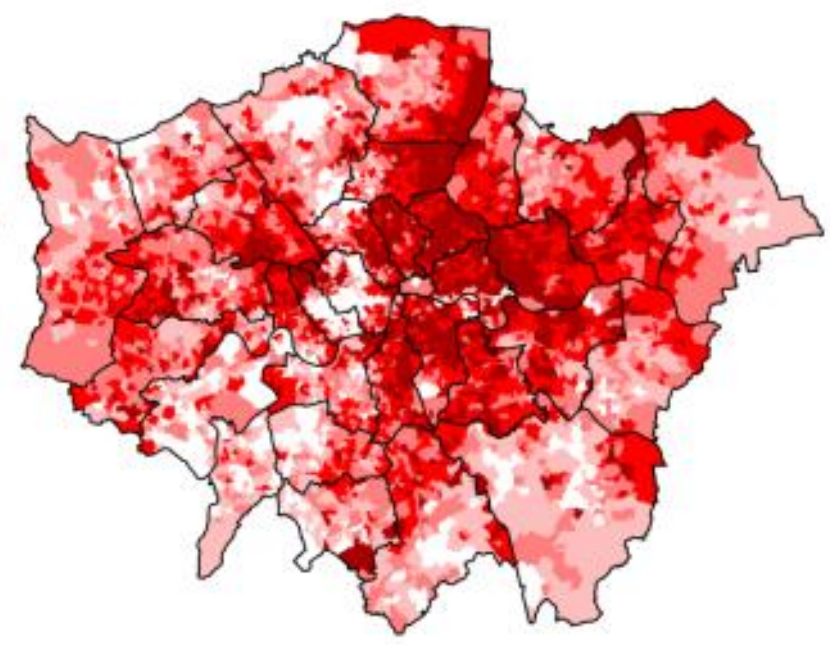


Figure 3 continued

Health

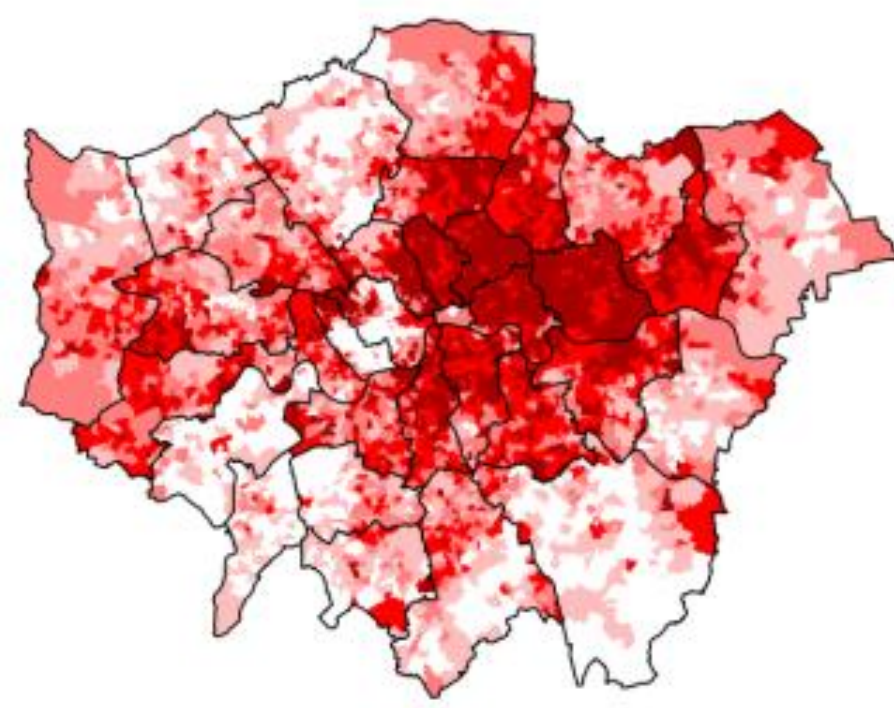

Education: adult

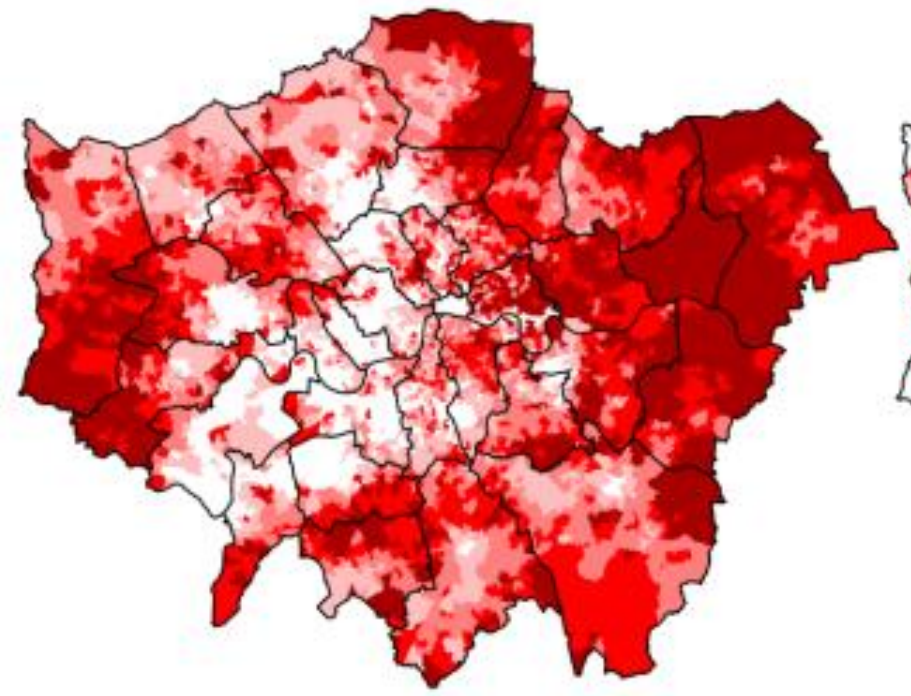

Education: child

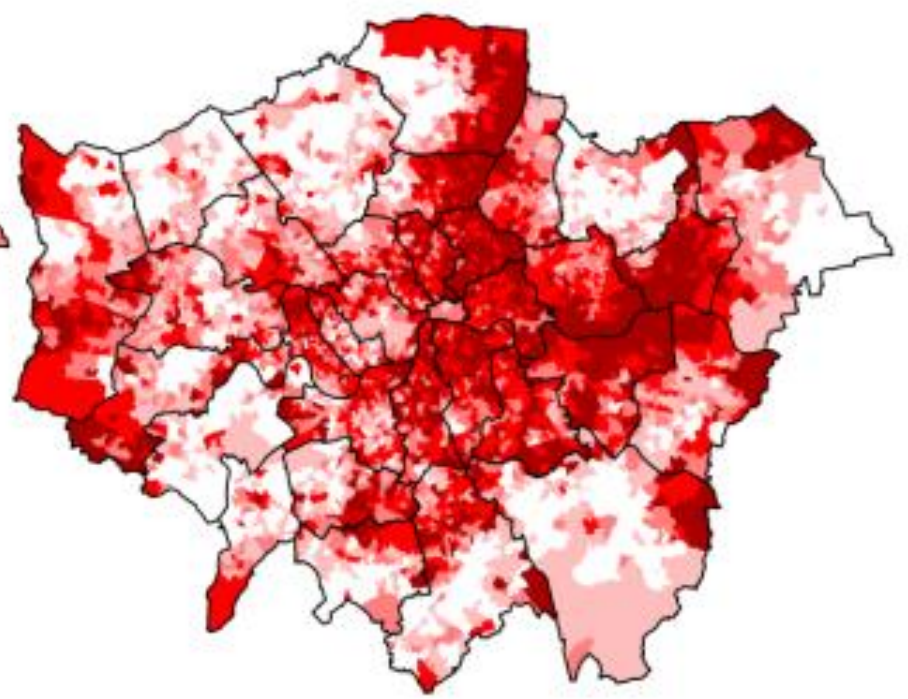

$\square$ Quintile 1 (low)

Quintile 2

Quintile 3

Quintile 4

Crime

Quintile 5 (high)

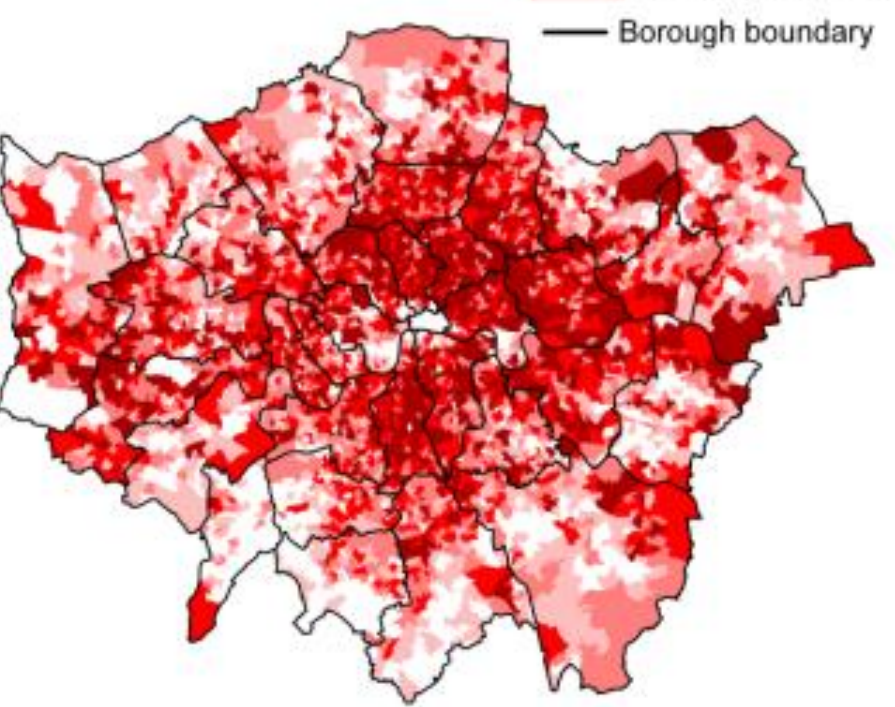


Figure 3 continued

Barriers: housing

Barriers: services
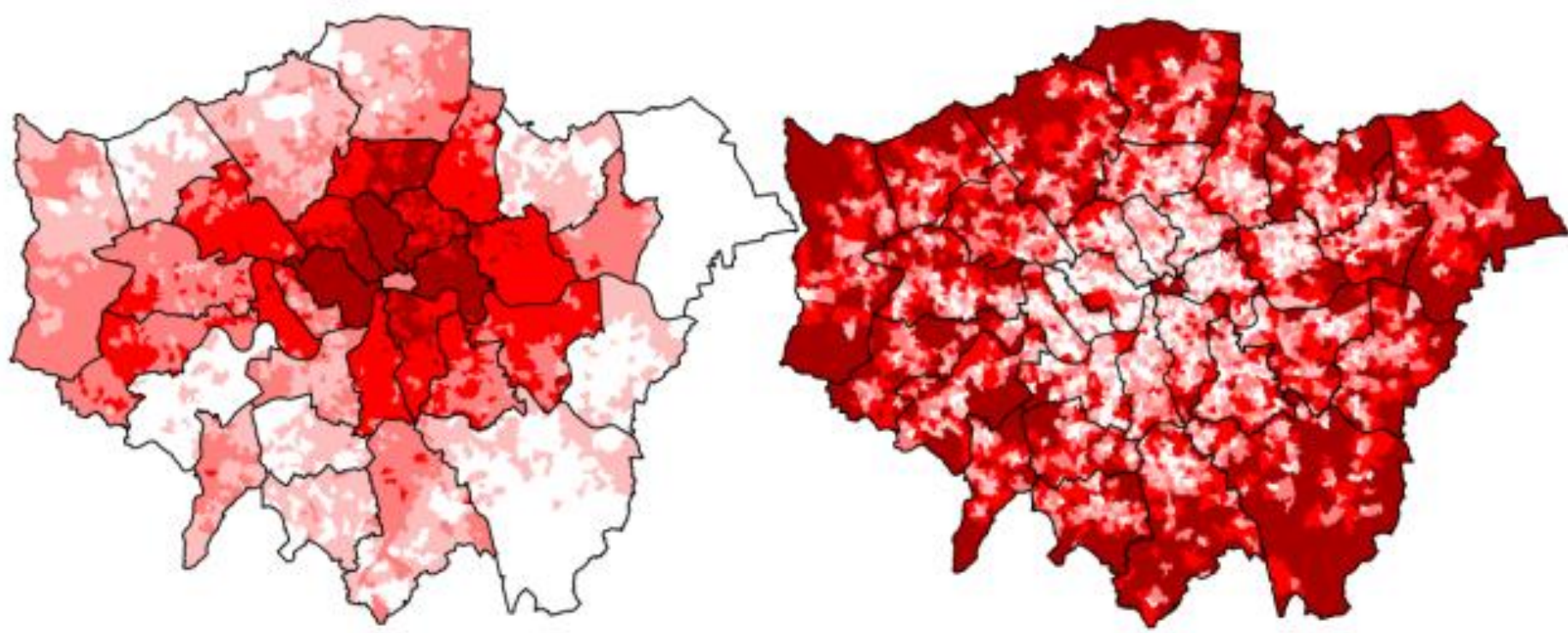

Environment: indoor

Environment: outdoor Quintile 1 (low) Quintile 2 Quintile 3 Quintile 4
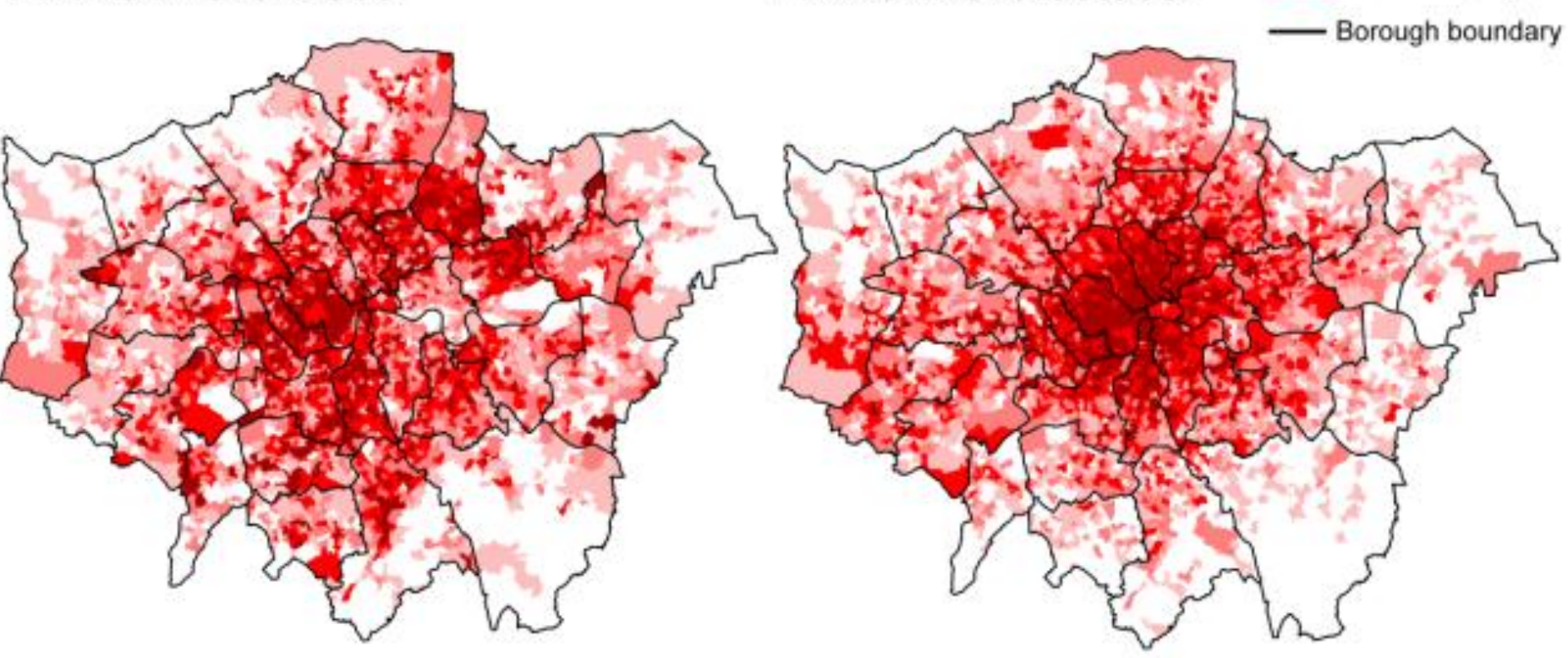
Table 6: Pearson correlation coefficients for the association between the IMD domains for 186424 residential postcodes in London

\begin{tabular}{|c|c|c|c|c|c|c|c|c|c|c|c|c|}
\hline & $\begin{array}{l}\text { Full } \\
\text { IMD04 }\end{array}$ & $\begin{array}{l}\text { IMD- } \\
\text { minus- } \\
\text { outdoor- } \\
\text { env. }\end{array}$ & Income & $\begin{array}{l}\text { Employ- } \\
\text { ment }\end{array}$ & Health & $\begin{array}{l}\text { Educ: } \\
\text { child }\end{array}$ & $\begin{array}{l}\text { Educ: } \\
\text { adult }\end{array}$ & Crime & $\begin{array}{l}\text { Barriers: } \\
\text { housing }\end{array}$ & $\begin{array}{l}\text { Barriers: } \\
\text { service }\end{array}$ & $\begin{array}{l}\text { Env: } \\
\text { indoor }\end{array}$ & $\begin{array}{l}\text { Env: } \\
\text { outdoor }\end{array}$ \\
\hline $\begin{array}{l}\text { Full IMD04 } \\
\text { IMD-minus- } \\
\text { outdoor-env. }\end{array}$ & $\begin{array}{l}1 \\
0.99 \\
\end{array}$ & 1 & & & & & & & & & & \\
\hline Income & 0.94 & 0.96 & 1 & & & & & & & & & \\
\hline Employment & 0.93 & 0.95 & 0.93 & 1 & & & & & & & & \\
\hline Health & 0.89 & 0.89 & 0.84 & 0.87 & 1 & & & & & & & \\
\hline Education: child & 0.75 & 0.76 & 0.72 & 0.66 & 0.70 & 1 & & & & & & \\
\hline Education: adult & 0.35 & 0.41 & 0.50 & 0.45 & 0.39 & 0.45 & 1 & & & & & \\
\hline Crime & 0.65 & 0.56 & 0.53 & 0.52 & 0.55 & 0.44 & 0.12 & 1 & & & & \\
\hline Barriers: housing & 0.72 & 0.68 & 0.54 & 0.54 & 0.63 & 0.50 & -0.16 & 0.45 & 1 & & & \\
\hline Barriers: service & -0.43 & -0.38 & -0.32 & -0.36 & -0.41 & -0.31 & 0.17 & -0.34 & -0.59 & 1 & & \\
\hline Env: indoor & 0.46 & 0.40 & 0.28 & 0.32 & 0.39 & 0.35 & -0.24 & 0.35 & 0.62 & -0.59 & 1 & \\
\hline Env: outdoor & 0.55 & 0.46 & 0.32 & 0.36 & 0.41 & 0.34 & -0.31 & 0.46 & 0.73 & -0.60 & 0.62 & 1 \\
\hline
\end{tabular}


Figure 4: Percent change in $\mathrm{NO}_{\mathrm{x}}$ concentrations by IMD domains, in residential postcodes in London ( $\mathrm{N}=186$ 424)
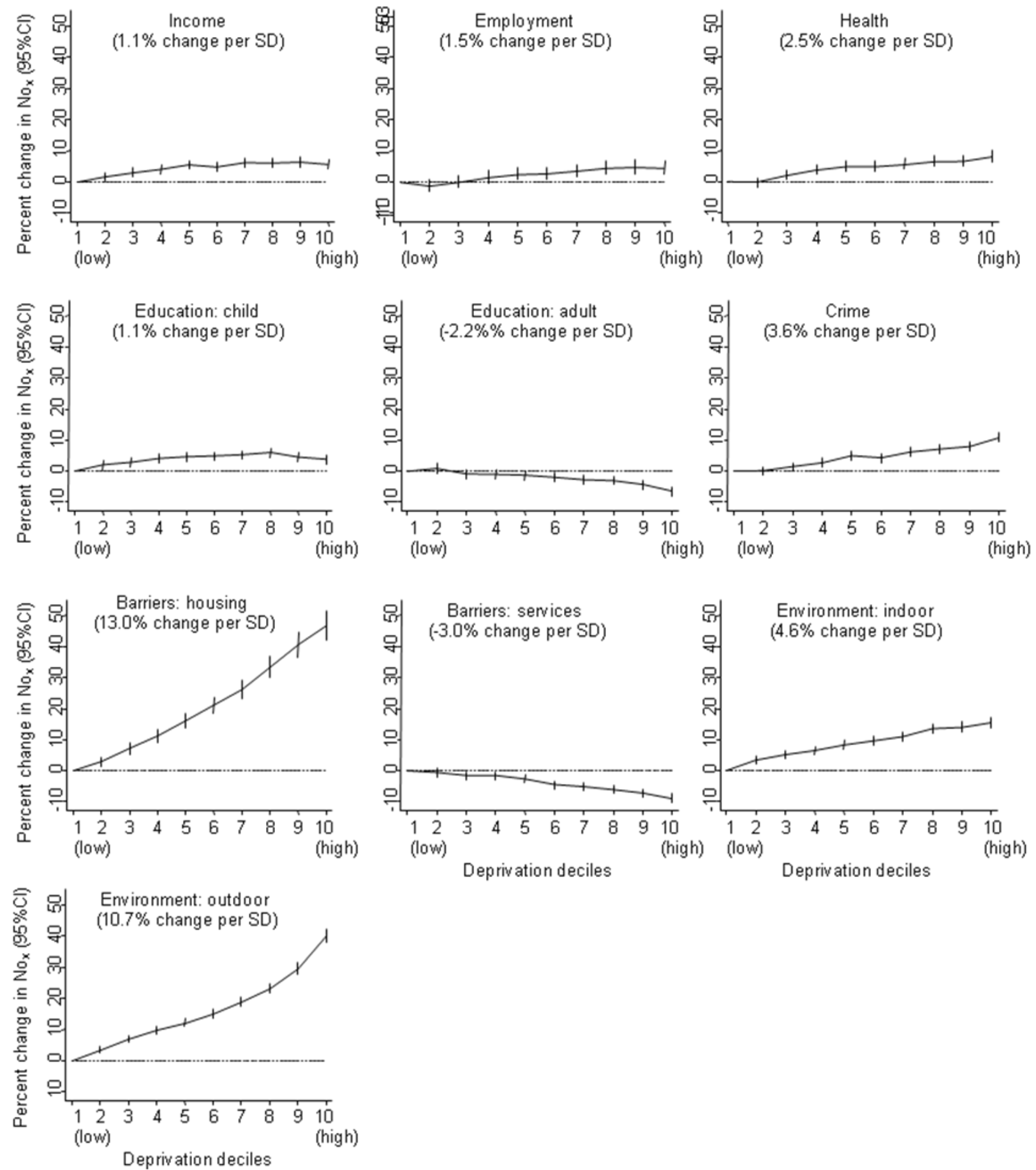

Values obtained from univariable regression analyses entering each IMD score in turn, and including three level random intercept model in which postcodes were nested within SOAs which were nested in boroughs. 
Table 7: Association between $\mathrm{NO}_{\mathrm{x}}$ concentrations and the 2004 IMD domains across zones of London

\begin{tabular}{|c|c|c|c|c|c|}
\hline & \multicolumn{5}{|c|}{ Adjusting for spatial autocorrelation $\uparrow$ : percent change $(95 \% \mathrm{CI})$ in $\mathrm{NO}_{\mathrm{x}}$} \\
\hline & London-wide & Central London & Non-central inner London & Outer London & Outside London \\
\hline & $N=186424$ & $N=30429$ & $\mathrm{~N}=38995$ & $\mathrm{~N}=92975$ & $\mathrm{~N}=24025$ \\
\hline Full IMD04 (z-score) & $2.7(2.3,3.2)$ & $-2.1(-3.5,-0.8)$ & $2.8(2.1,3.5)$ & $3.5(2.9,4.0)$ & $0.8(-0.5,2.2)$ \\
\hline IMD-minus-outdoor-env (z-score) & $1.6(1.2,2.0)$ & $-2.3(-3.6,-1.0)$ & $1.5(0.8,2.2)$ & $2.2(1.7,2.8)$ & $0.3(-1.0,1.6)$ \\
\hline Income (z-score) & $1.1(0.8,1.5)$ & $-2.8(-3.9,-1.7)$ & $1.0(0.4,1.6)$ & $1.9(1.4,2.4)$ & $0.6(-0.7,1.9)$ \\
\hline Employment (z-score) & $1.5(1.1,1.8)$ & $-1.8(-2.9,-0.8)$ & $1.3(0.7,1.8)$ & $2.5(1.9,3.0)$ & $1.2(-0.2,2.6)$ \\
\hline Health (z-score) & $2.5(2.0,3.0)$ & $-1.0(-2.4,0.4)$ & $2.4(1.6,3.3)$ & $3.6(2.9,4.2)$ & $1.5(0.5,2.5)$ \\
\hline Education: child (z-score) & $1.1(0.7,1.5)$ & $-2.0(-4.0,0.1)$ & $1.0(0.1,1.9)$ & $1.0(0.6,1.5)$ & $0.8(0.1,1.5)$ \\
\hline Education: adult (z-score) & $-2.2(-2.5,-1.8)$ & $-3.3(-4.6,-2.0)$ & $-1.8(-2.4,-1.1)$ & $-3.1(-3.6,-2.6)$ & $1.1(0.2,2.0)$ \\
\hline Crime (z-score) & $3.5(3.1,3.8)$ & $-1.9(-3.0,-0.8)$ & $4.6(3.9,5.3)$ & $4.6(4.1,5.1)$ & $1.8(0.7,2.9)$ \\
\hline Barriers: housing (z-score) & $13.1(12.1,14.2)$ & $2.7(-1.6,7.2)$ & $13.1(10.6,15.8)$ & $14.1(12.8,15.5)$ & $3.2(1.6,4.9)$ \\
\hline Barriers: service (z-score) & $-3.0(-3.4,-2.7)$ & $-0.5(-2.1,1.3)$ & $-1.9(-2.6,-1.2)$ & $-3.5(-3.9,-3.0)$ & $-2.2(-2.8,-1.5)$ \\
\hline Environment: indoor (z-score) & $4.7(4.3,5.1)$ & $3.9(2.1,5.8)$ & $3.0(2.1,4.0)$ & $5.5(5.1,6.0)$ & $1.9(1.1,2.7)$ \\
\hline Environment: outdoor (z-score) & $10.6(10.1,11.0)$ & $10.9(9.0,12.8)$ & $10.6(9.8,11.3)$ & $10.2(9.6,10.8)$ & $4.7(3.5,5.9)$ \\
\hline
\end{tabular}

$\dagger$ We adjusted for spatial autocorrelation using a three level random intercept model in which postcodes were nested within SOAs which were nested in boroughs.

Figure 5: Mean IMD04 score by ACORN group in residential postcodes in London ( $N=186$ 424)

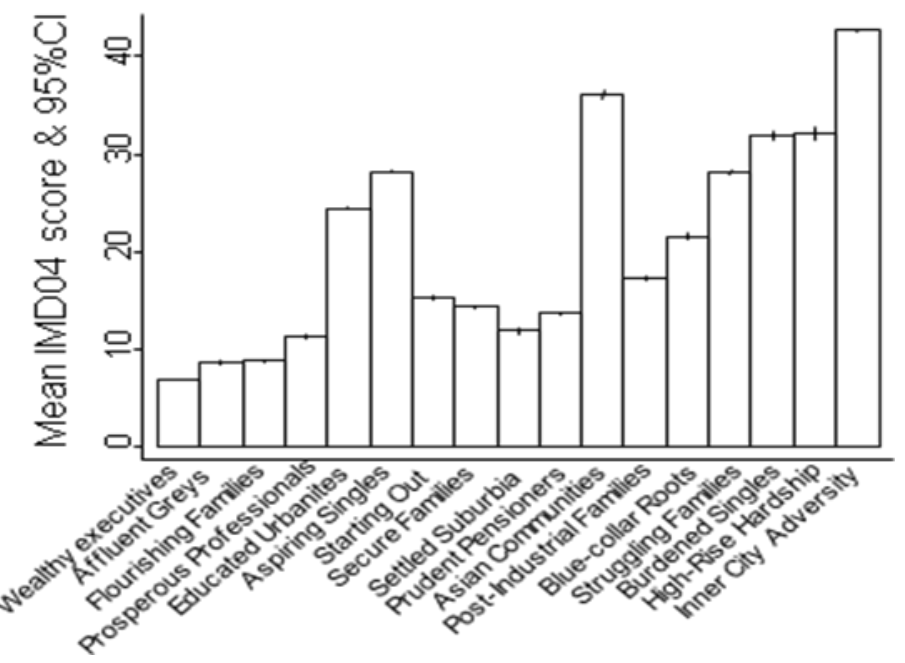


Table 8: Percent change in $\mathrm{NO}_{\mathrm{x}}$ concentrations in multivariable analyses of IMD domains and ACORN across different parts of London

\begin{tabular}{|c|c|c|c|c|c|c|}
\hline & & \multicolumn{5}{|c|}{ Percent increase $(95 \% \mathrm{CI})$ in $\mathrm{NO}_{\mathrm{x}}$ per unit increase in value in explanatory factor } \\
\hline & & $\begin{array}{l}\text { London-wide ( } N=186 \\
\text { 424) }\end{array}$ & $\begin{array}{l}\text { Central London } \\
(\mathrm{N}=30 \text { 429) }\end{array}$ & $\begin{array}{l}\text { Non-central inner } \\
\text { London }(\mathrm{N}=38 \text { 995) }\end{array}$ & $\begin{array}{l}\text { Outer London ( } N=92 \\
\text { 975) }\end{array}$ & $\begin{array}{l}\text { Outside London } \\
(\mathrm{N}=\mathbf{2 4} 025)\end{array}$ \\
\hline $\begin{array}{l}\text { IMD } \\
\text { domains } \\
\text { (z-score) }\end{array}$ & $\begin{array}{l}\text { Employment } \\
\text { Education: child } \\
\text { Education: adult } \\
\text { Crime } \\
\text { Barriers: housing } \\
\text { Barriers: service } \\
\text { Environment: indoor }\end{array}$ & $\begin{array}{l}1.1(0.6,1.6) \\
0.1(-0.4,0.6) \\
-3.8(-4.3,-3.3) \\
1.8(1.4,2.1) \\
9.7(8.4,11.0) \\
-1.2(-1.6,-0.9) \\
0.8(0.4,1.2)\end{array}$ & $\begin{array}{l}0.2(-1.4,1.9) \\
-0.9(-3.0,1.3) \\
-1.9(-4.0,0.3) \\
-1.6(-2.7,-0.5) \\
7.5(3.4,11.7) \\
-0.2(-1.9,1.4) \\
2.5(0.8,4.2)\end{array}$ & $\begin{array}{l}1.6(0.7,2.4) \\
0.8(-0.2,1.7) \\
-4.1(-5.0,-3.2) \\
3.3(2.6,4.0) \\
12.6(9.5,15.7) \\
-0.5(-1.1,0.2) \\
0.7(-0.1,1.6)\end{array}$ & $\begin{array}{l}1.2(0.5,1.9) \\
0.2(-0.5,0.8) \\
-4.9(-5.5,-4.3) \\
2.5(2.1,3.0) \\
7.6(6.0,9.2) \\
-1.1(-1.5,-0.6) \\
1.1(0.6,1.6)\end{array}$ & $\begin{array}{l}-1.4(-3.4,0.6) \\
-0.2(-1.5,1.1) \\
1.1(-0.5,2.7) \\
1.1(-0.1,2.3) \\
0.0(-2.2,2.2) \\
-1.5(-2.2,-0.8) \\
0.4(-0.5,1.4)\end{array}$ \\
\hline $\begin{array}{l}\text { Model } \\
\text { components } \\
\text { of variance }\end{array}$ & $\begin{array}{l}\text { Level 3: Borough-level } \\
\text { Level 2: SOA-level } \\
\text { Level 1: Postcode-level }\end{array}$ & $\begin{array}{l}0.01 \\
0.01 \\
0.02 \\
\end{array}$ & $\begin{array}{l}0.00 \\
0.01 \\
0.03\end{array}$ & $\begin{array}{l}0.01 \\
0.01 \\
0.02\end{array}$ & $\begin{array}{l}0.00 \\
0.01 \\
0.01\end{array}$ & $\begin{array}{l}0.00 \\
0.01 \\
0.01 \\
\end{array}$ \\
\hline $\begin{array}{l}\text { Intra-class } \\
\text { correlation }\end{array}$ & $\begin{array}{l}\text { Level 3: Within boroughs } \\
\text { Level 2: Within SOAs }\end{array}$ & $\begin{array}{l}0.33 \\
0.55 \\
\end{array}$ & $\begin{array}{l}0.03 \\
0.26 \\
\end{array}$ & $\begin{array}{l}0.21 \\
0.43 \\
\end{array}$ & $\begin{array}{l}0.12 \\
0.44 \\
\end{array}$ & $\begin{array}{l}0.21 \\
0.49 \\
\end{array}$ \\
\hline $\begin{array}{l}\mathbf{R}^{2} \text { (percent } \\
\text { of variance } \\
\text { explained) }\end{array}$ & $\begin{array}{l}\text { Total } \\
\text { Level 3: Borough level } \\
\text { Level 2: SOA-level } \\
\text { Level 1: Postcode-level }\end{array}$ & $\begin{array}{l}0.55 \\
0.78 \\
0.25 \\
0.01 \\
\end{array}$ & $\begin{array}{l}0.10 \\
0.70 \\
0.12 \\
0.01 \\
\end{array}$ & $\begin{array}{l}0.22 \\
0.48 \\
0.29 \\
0.01 \\
\end{array}$ & $\begin{array}{l}0.39 \\
0.80 \\
0.35 \\
0.02 \\
\end{array}$ & $\begin{array}{l}0.07 \\
0.11 \\
0.12 \\
0.02 \\
\end{array}$ \\
\hline
\end{tabular}

All variables are adjusted for all other variables in the column. Note that unlike in the main text the baseline ACORN group used here is 'educated urbanites' as this is one of the only groups with over 200 individuals in each part of London. Cells in square brackets correspond to values based on fewer than 20 individuals. 
Figure 6: Percent high individual-level SEP and current smokers by IMD04 deciles and ACORN categories, in the Whitehall II cohort $(\mathrm{N}=3654)$
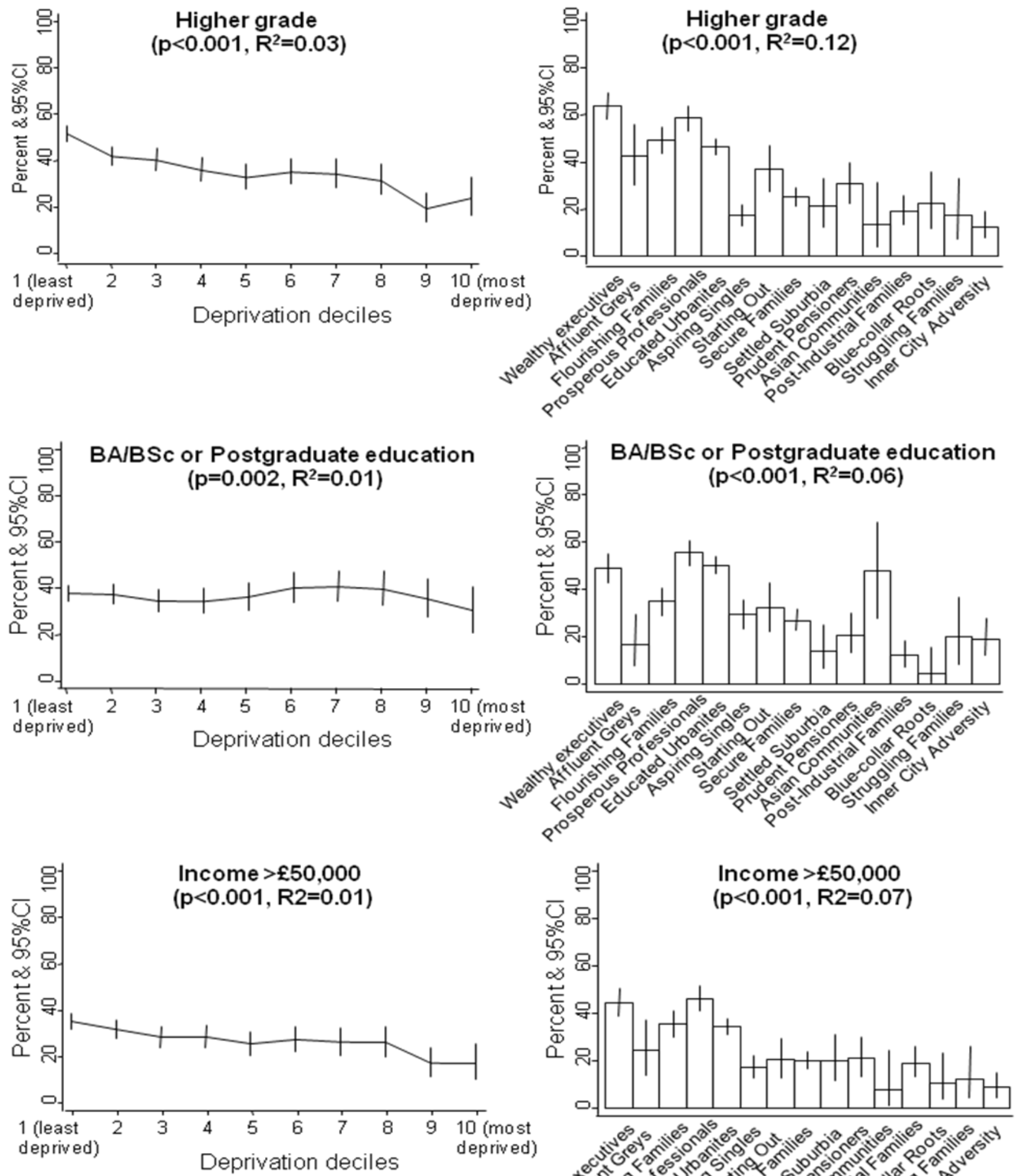
Figure 6 continued

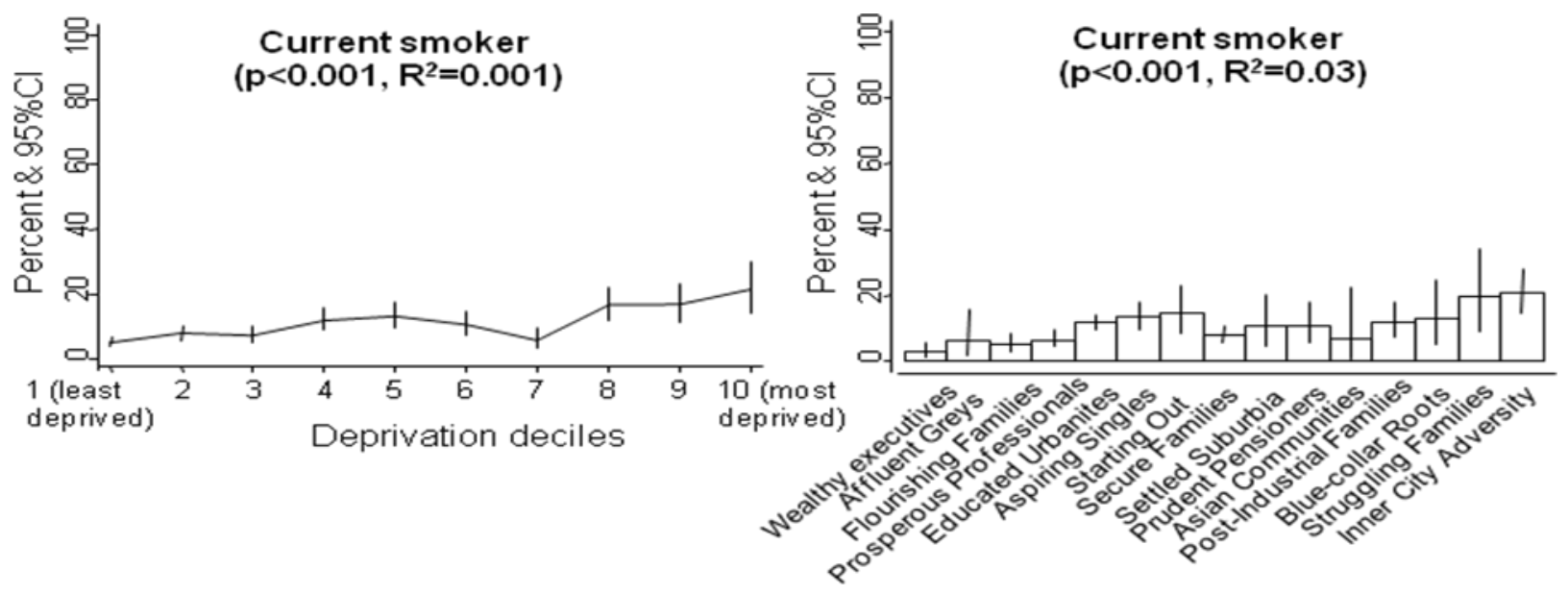

p-values from tests for heterogeneity. 'Burdened Singles' and 'High-Rise Hardship' ACORN categories excluded as only 10 Whitehall II cohort members were in each group. 